\title{
Memoria Histórica y Patrimonio. Consideraciones conceptuales y metodológicas aplicadas al caso de Sevilla
}

\author{
Historical Memory and Heritage. Conceptual and Methodological \\ Consirations in the Case of Seville
}

\author{
Víctor Fernández Salinas* \\ Universidad de Sevilla \\ https://orcid.org/0000-0003-4244-1018 \\ salinas@us.es \\ Rocío Silva Pérez \\ Universidad de Sevilla \\ https:/ / orcid.org/0000-0002-0643-7591 \\ rsilva@us.es
}

Recibido: 28/05/2020; Revisado: 18/10/2020; Aceptado: 22/10/2020

\begin{abstract}
Resumen
Este artículo analiza el rango patrimonial y la inserción territorial de nueve Lugares de Memoria Histórica y Democrática de Andalucía en Sevilla (declarados, incoados o propuestos). Para ello se determinarán los claroscuros desde la perspectiva geográfica de la forma con la que se han concebido estos lugares y su proyección espacial. El método del trabajo, extrapolable a otros territorios y ciudades, facilitará un campo de reflexión geográfica poco desarrollado hasta el momento y que puede servir de marco a reivindicaciones sociales urgentes sobre cómo gestionar una memoria que plantea aún graves disensiones políticas locales, autonómicas y nacionales en España.
\end{abstract}

Palabras clave: Sevilla, Andalucía, Lugares de Memoria Histórica, Lugares de Memoria Democráctica, Patrimonio.

*Autor de correspondencia / Corresponding author.

Copyright: (C) 2021 ULPGC. Este es un artículo de acceso abierto distribuido bajo los términos de la licencia Creative Commons Atribución-NoComercial-SinDerivar (by-nc-nd) Spain 3.0. 


\begin{abstract}
This paper analyses the patrimonial range and territorial integration of nine Historical and Democratic Memorial Sites of Andalusia within Seville (whether declared, initiated or proposed). The lights and shades of this topic derive from a geographical perspective regarding the way these places and their spatial projection have been conceived. The methodology of this work, extrapolable to other territories and cities, can contribute to a field of geographical reflection as yet underdeveloped. It can serve as a framework for urgent social demands on how to manage those memories that still cause serious local, regional and national political disagreements in Spain.
\end{abstract}

Key words: Seville, Andalusia, Historical Memorials, Democratic Memorials, Heritage.

\title{
1. INTRODUCCIÓN
}

La memoria histórica ha sido objeto de creciente reflexión científica en España desde los últimos decenios del siglo xx (ANDRÉs, 2008) y está muy ligada al espacio en el que se desarrollan los hechos que conmemora; sin embargo, los estudios geográficos para conceptualizar y analizar los lugares a los que hace referencia no son numerosos (GARCía Álvarez, 2009). Esto es especialmente significativo, no solo porque en otros ámbitos ese esfuerzo lleva tiempo siendo objeto de la reflexión geográfica (FoOte y AZARYAHu, 2007; Hoelscher y AldDERMAN, 2004; TILL, 2003) o porque en España el interés por estos lugares lo llevan otros investigadores sociales (COLMeIro, 2005; RuIz, 2007; RoMERo, 2009), sino porque se están desarrollando normativas que, al reivindicar esta memoria, lo hacen a través de la figura de lugares de la memoria histórica (o nombres equiparables) de claro interés geográfico. En este contexto, la aportación de conceptos y métodos con los que entender la inserción territorial de estos lugares y la identificación de las claves para su protección y gestión se entienden como la justificación básica de este artículo.

\section{OBJETIVOS, MÉTODO Y FUENTES}

En consonancia con los planteamientos antes esbozados, los objetivos del trabajo son:

a) Reflexionar desde la perspectiva espacial y patrimonial sobre los conceptos y figuras relacionados con la memoria histórica.

b) Establecer una metodología para el análisis de los lugares de la memoria histórica que incluya una tipología de estos lugares y una ficha que aporte orden y método para su identificación y valoración.

c) Complementando el punto anterior, introducir el concepto de escenario de memoria histórica (en adelante escenario) como marco espacial de entendimiento de los citados lugares.

d) Centrar la reflexión en el caso de Sevilla a través de dos escalas: la global del municipio y la de dos lugares de memoria como casos de estudio.

Para alcanzar los objetivos, se ha partido de una revisión teórica y conceptual de los términos relacionados con el objeto del trabajo (lugares y escenarios de memoria histórica, bienes patrimoniales memorialistas y espíritu de lugar). 
A continuación, y acercándose al objeto principal del trabajo (los lugares de la memoria histórica de Sevilla), se ofrece el marco normativo autonómico que lo rige y se propone la aproximación al conocimiento de este objeto en dos escalas: a) en la escala general del municipio de Sevilla y b) en escalas particulares definidas en razón a las características propias de dos Lugares de Memoria Histórica y Democrática y sus escenarios.

Respecto a la escala general se determinará una mirada conjunta de todos los bienes reconocidos atendiendo a su origen, tipo, contextualización, distribución y tipo de escenarios en los que se insertan (individuales o compartidos). En cuanto a la escala específica de los lugares de la memoria histórica, se ha ideado un método analítico-prospectivo de identificación (incluyendo una diferenciación tipológica: Tabla 1), definición y consideración patrimonial teniendo en cuenta los presupuestos del espíritu del lugar).

Para la recopilación de esta información se propone la elaboración de una ficha (Tabla 2) estructurada con el objeto de proporcionar la información necesaria para el análisis y valoración de cada lugar. Este artículo acuña el concepto de escenario pero no lo agota, sino que se centra en saber en qué medida cada lugar de memoria analizado influye en el escenario en el que se ubica. Por razones de espacio, la profundización y el análisis exhaustivo de esos escenarios se relegan para estudios posteriores.

Por la misma razón también es imposible aplicar el método a todos los Lugares de Memoria Histórica y Democrática del municipio de Sevilla. Se analizan aquí, como ensayo de la propuesta, dos estudios de caso contrastados: el Lugar de Memoria Histórica del fusilamiento de Blas Infante y la Jefatura Superior de Policía de la Gavidia.

TABLA 1

Tipología de lugares de memoria histórica

\begin{tabular}{|l|l|}
\hline \multicolumn{2}{|l|}{ Espacios e infraestructuras públicos } \\
\hline Viario urbano & Calles, plazas, avenidas, etc. \\
\hline Dotacionales & Parques, cementerios, canales, etc. \\
\hline Edificios públicos & Ayuntamientos, diputaciones, gobiernos civiles, etc. \\
\hline Institucionales & Hospitales, escuelas, juzgados, etc. \\
\hline Dotacionales genéricos & $\begin{array}{l}\text { Fortalezas, cárceles, comisarías, refugios, cuarteles, fábricas } \\
\text { militares, etc. }\end{array}$ \\
\hline Dotacionales de seguridad \\
\hline Espacios y edificios privados & $\begin{array}{l}\text { Viviendas, sedes institucionales, periódicos, centros de ocio, } \\
\text { empresas, etc. }\end{array}$ \\
\hline Civiles & Iglesias, residencias conventuales y monásticas, etc. \\
\hline Religiosos & Otros (cualquier otro escenario no encuadrable en los epígrafes anteriores) \\
\hline
\end{tabular}

Fuente: Elaboración propia 
Memoria Histórica y Patrimonio. Consideraciones conceptuales y metodológicas...

TABLA 2

Modelo de ficha para el análisis de los lugares de la memoria histórica y sus escenarios

\begin{tabular}{|l|}
\hline A) Nombre: \\
\hline B) Tipología: \\
\hline C) Carácter del escenario en el que se inserta: \\
\hline D) Reconocimientos oficiales: \\
a) Memorialista \\
b) Patrimonial no memorialista \\
c) Otros \\
\hline E) Localización y emplazamiento: \\
a) Ubicación \\
b) Emplazamiento \\
c) Vista oblicua \\
d) Fografía(s) \\
\hline F) Otras imágenes de contenido histórico: \\
\hline G) El escenario: \\
a) Tipo (individual o compartido) \\
b) Descripcióngeneral (individual) o aportación dellugar dememoria al escenario (compartido) \\
c) Propiedad, función y gestión \\
d) Cambios operados desde el momento en que se relacionó con la memoria \\
d) Inserción en el entramado urbano \\
f) Hitos y otros elementos destacados \\
g) Ambientación urbana \\
\hline H) Percepciones-cualificación del escenario: \\
a) Sociales \\
b) Experienciales y creativas \\
\hline I) Determinación sintética del espíritu del lugar, núcleo de sentido: \\
\hline J) Propuesta de delimitación del escenario y medidas que mejoren sus potenciales: \\
a) Propuesta de delimitación \\
b) Medidas propuestas \\
\hline
\end{tabular}

Fuente: Elaboración propia.

Respecto a las fuentes, además de la bibliografía que se relaciona al final del trabajo, hay que citar dos textos legales: el Decreto 264/2001 sobre Creación y Regulación de los Lugares de Memoria Histórica de Andalucía y su Catálogo y la Ley 2/2017 sobre Memoria Histórica y Democrática de Andalucía. También ha sido de interés, entre otros documentos que también se citan al final, el «Informe de seguimiento de las actuaciones en materia de memoria democrática 2017-2018» de la Consejería de la Presidencia, Administración Local y Memoria Democrática de la Junta de Andalucía (2019). Por su parte, el trabajo de campo ha permitido reconocer in situ las circunstancias actuales por las que pasan los dos casos de estudio, para los que se han recogido materiales fotográficos y descriptivos. 


\section{MEMORIA HISTÓRICA, PATRIMONIO Y ESPÍRITU DEL LUGAR}

\subsection{La memoria histórica y sus conceptos clave}

La memoria histórica, sobre todo desde finales del siglo $\mathrm{xx}$, ha devenido un concepto global (CARRETERO, 2007; HALBWACHS y LASÉN, 1995), avalado además por resoluciones muy directamente relacionadas con las más altas instituciones de rango internacional (resoluciones de las Naciones Unidas sobre los derechos de víctimas de violaciones; sobre impunidad y sobre el derecho a la verdad). Detrás de este proceso se evidencia una manera distinta de entender y realizar el duelo social ante hechos luctuosos, la mayor parte de ellos relacionada con conflictos bélicos o con represiones dictatoriales, y que no tienen parangón con la respuesta que otros hechos similares (aunque no tan globales) habían tenido en el pasado. El inicio de esta corriente puede situarse tras la Segunda Guerra Mundial (Halbwachs, 1968), pero su eco e incidencia se ha hecho más potente en los últimos decenios del siglo $\mathrm{xx}$, especialmente a partir de la aportación en Francia de Pierre Nora y su vasta obra sobre los lugares de la memoria (1984-1992) y de su repercusión en otros países, entre ellos España (Aguilar, 1996; Colmeiro, 2005) y otros países latinoamericanos (MORA, 2013). La memoria histórica es una reclamación de las bases sociales (asociaciones memorialistas, sindicatos, entidades locales, particulares) que reivindican una relectura de hechos históricos conflictivos sin resolver por el conjunto de la comunidad y que centra su discurso en la reparación y dignificación de las víctimas, normalmente los vencidos y agraviados por los hechos históricos de referencia. La memoria histórica no es, o no es solo, un hecho histórico delimitable en el tiempo y en el espacio, sino un proceso en el que las víctimas y sus familiares y allegados, articulan esa memoria para generar identidad y autoafirmación (EsCUDERO, 2018). Tampoco se puede decir que memoria histórica e historia, por cerca que se encuentren, sean lo mismo. La historia se refiere a hechos del pasado objetivamente probados a través de fuentes fiables; en cambio, la memoria histórica, aunque entronca con la anterior, tiene que ver más con los recuerdos, los sentimientos y las percepciones que con las objetividades científicas; sus bases son más subjetivas y cambiantes $\mathrm{y}$, a diferencia de la historia, la memoria histórica siempre es presente. Ello la acerca más al mundo del patrimonio, tal como este se entiende hoy como proceso de asignación de valores (MANZINI, 2011).

El citado Pierre NoRA va más allá y entiende por historia una mirada parcial y conflictiva de lo que ya no es; memoria histórica sería un concepto mucho más rico, vivo, mutable y con ritmos alternantes de recuperación y olvido (1989). La historia, con sus acuerdos y disensiones sociales, es de todos; la memoria es propia de un grupo, de sus reivindicaciones, afectos e identidades $y$, en el proceso de hacerla asertiva y universal, a menudo se vuelve difícil de gestionar ya que siempre comporta dosis de dolor propio y de incomprensión e ignorancia por parte de los que no empatizan con su mensaje. 
Memoria Histórica y Patrimonio. Consideraciones conceptuales y metodológicas...

\subsubsection{Lugares de memoria histórica, Lugares de Memoria Histórica y Lugares de Memoria Democrática}

No es objeto de este artículo realizar una reflexión o aportación general sobre lo que ha significado la memoria histórica, cuestión que desbordaría su objeto, sino centrarse en la proyección espacial de esta memoria desde la perspectiva patrimonial y geográfica. Para ello, es importante establecer las siguientes reflexiones y definiciones:

Los lugares de memoria histórica se conciben aquí como aquellos espacios connotados por un conflicto histórico que ha dejado huellas dolorosas física y psicológicamente en los habitantes (en todos o en una parte) de un territorio determinado; ${ }^{1}$ en otras palabras, son la proyección espacial de dicha memoria. El reconocimiento patrimonial de estos lugares ha seguido caminos complejos $\mathrm{y}$, si bien hay aspectos comunes (didácticos, de respeto y solemnidad, etc.), la manera de enfocar su activación social para evitar su olvido (RIELF, 2017) no siempre ha sido homogénea o coherente. La Segunda Guerra Mundial ha llenado el mundo de lugares que, en algunos casos, han alcanzado la más alta categoría patrimonial. Así, "Auschwitz-Birkenau. Campo de concentración y exterminio alemán nazi, 1940-1945» se integró al año siguiente de inaugurarse la Lista del Patrimonio Mundial de la Unesco (en 1979); en Argentina, la Escuela Mecánica de la Armada, lugar de represión durante la dictadura militar entre 1976 y 1983, también ha sido postulada (hasta el momento sin éxito) a la misma Lista. En países como Francia, se habla incluso de altos lugares de memoria del Ministerio de las Armadas (hauts lieux de mémoire) como espacios en los que se concreta la épica. Sin embargo, no se puede hablar de una teoría homogénea y monolítica en la escala mundial que oriente este proceso de entendimiento y patrimonialización de espacios ligados a la memoria histórica (CARRIER, 2005; HEIN y SELDEN, 2000).

En este trabajo, matizando la definición de Icomos antes presentada, se entiende como lugar de memoria histórica aquel ámbito espacial que está ligado a un hecho histórico de carácter luctuoso en el que las víctimas son, principalmente, civiles que ven conculcados sus derechos básicos y son sometidos a algún tipo de represión por su ideología, orientación sexual, convicciones religiosas o cualquier otra razón que venga amparada por los derechos humanos. Para evitar confusiones, la expresión lugar de memoria histórica se escribe en minúscula en este trabajo cuando se hace referencia al concepto anterior (espacial y teórico) de forma genérica y se usará con mayúsculas iniciales cuando se trate de los Lugares de Memoria Histórica de Andalucía creados por el Decreto 264/2011 que les dio carta de naturaleza (concepto normativo) y que serán analizados más adelante.

Para mantener la coherencia con este criterio, también se escribirán con mayúscula los Lugares de Memoria Democrática cuyo inventario fue concebido por la Ley 2/2017 de Memoria Histórica y Democrática de Andalucía (por lo tanto, también concepto normativo).

1 Icomos, 2017: Documento orientativo de Icomos acerca de la recuperación y recuperación post trauma para propiedades culturales del Patrimonio Mundial [en línea]. Disponible en: http://openarchive.icomos. org/1763/34/ICOMOS\%20Guidance \%20on \% 20Post\%20trauma \%20Recovery\%20-\%20Spanish \% 20 version.pdf [Consultado: 13/12/2019]. 


\subsubsection{Escenarios}

Los lugares de la memoria histórica se suelen identificar de forma segregada, de uno en uno, y, además, desligados de su entorno territorial. Para superar esto, en este trabajo se acuña el concepto de escenario con el objeto de, desde una perspectiva geográfica e integral, contextualizar los bienes memorialistas en el espacio y, en relación con ello, para determinar su tutela y gestión en este marco espacial. Se compone del elemento rememorativo de la memoria propiamente dicho (un inmueble, una pintada, una fosa, etc.) y el ámbito en que este se integra (una plaza, un cementerio, un cruce de caminos, etc.).

Los escenarios expresan la interrelación que existe entre elementos memorialistas y el marco espacial en el que se apoya la memoria Ello da pie a diferenciar entre escenarios individuales, cuando se corresponden con un único lugar de memoria (por ejemplo, el lugar de apresamiento de activistas maquis en una cueva o una cárcel) o compartidos, cuando en un mismo ámbito coinciden dos lugares de memoria o más (por ejemplo, un área en la que estuvieran cercanos varios cuarteles, lugares utilizados como presidios o plazas en las que se desarrollaron actos violentos); se estaría en ese caso ante elementos que precisarían un entendimiento más profundo, complejo y adecuado.

El escenario de la memoria histórica se acerca al concepto de entorno (como ámbito que protege un bien), pero en este caso adquiere sustancia y significado en sí mismo. Los entornos (al menos los de los bienes de interés cultural españoles; art. 18. ${ }^{\circ}$ de la Ley del Patrimonio Histórico Español, 1985), son inseparables de los bienes a los que protegen; el escenario (un área física, perceptiva y simbólica) completa, redefine y articula el mensaje y símbolo de un lugar de memoria histórica.

\subsection{El nuevo paradigma patrimonial como referente de la memoria histórica}

Tal y como se ha señalado, a diferencia de la historia, la memoria histórica siempre es presente y ello la acerca a los conceptos de patrimonio y patrimonialización; que son entendidos actualmente como los elementos materiales e inmateriales a los que se les han asignados valores (patrimonio) y el proceso de esta asignación (patrimonialización). Los valores pueden ser de carácter identitario, de abajo arriba, e institucionales, de arriba abajo. Pero en ese entendimiento actual del patrimonio la memoria histórica posee matices propios y distintivos por el peso que en ella tiene el abajo, la sociedad civil, contrariamente a lo que acontece en los reconocimientos patrimoniales convencionales, en los que el predominio recae en el arriba: las declaraciones institucionales. Ello dota a la memoria histórica de una especificidad en el mundo del patrimonio no exenta de contradicciones, ya que a menudo la patrimonialización de esta memoria, aunque el valor venga desde abajo, se reconoce (mediante leyes patrimoniales o similares) desde arriba.

La patrimonialización de la memoria histórica desde la sociedad civil está indisolublemente ligada a la manera variada y distinta con la que las distintas culturas entienden los duelos y la forma de superarlos y, dentro de una misma cultura, a la percepción diferenciada del hecho luctuoso por colectivos sociales y 
políticos. Esa condición poliédrica de la memoria histórica y de los procesos de patrimonialización que la promueven está siempre ligada, trátese de testimonios materiales o inmateriales, a espacios concretos; ello dota a esta memoria de una marcada espacialidad. El patrimonio como identidad compartida, y no solo el de la memoria histórica, cuando se crea desde abajo no siempre se concreta en objetos o símbolos tangibles, pero siempre se ancla a un espacio, fuera del cual es difícilmente comprensible. Hay un remedo de los sanfermines en Petersburg, Estados Unidos, pero nunca serán los sanfermines de Pamplona por mucho que imiten ritos y formas. Con la memoria histórica sucede algo similar, ya que también está amarrada a los sitios (cuarteles, tapias de cementerios, fosas, etc.) $\mathrm{y}$ a los hechos concretos que conmemoran (reclusiones, fusilamientos, torturas, etc.); pero los hechos rememorados (la memoria) se mantiene (se aspira a que se perpetúe) al tiempo que los espacios cambian. La relación espacio-tiempo en cuestión de memoria histórica es dialéctica y cambiante, particularmente en lo que tiene que ver con el espacio, en tanto que ente esencialmente dinámico y refractario a la fosilización.

El encadenamiento entre espacio e historia tiene ya una larga trayectoria en el mundo del patrimonio, pero desde ese campo no se ha acometido en toda su complejidad la dimensión espacial de los bienes patrimoniales, tampoco en el caso de los denominados sitios históricos (HERnANDO, 2009). Existe una carta internacional, la de los Jardines [y Sitios Históricos] de Icomos, ${ }^{2}$ pero en ella la relación entre memoria histórica y estos sitios no es objeto de referencias específicas. No obstante, la definición de sitio histórico de esta carta es bastante esclarecedora: «Un sitio histórico es un paisaje específico asociado a un hecho memorable como, por ejemplo, un suceso histórico importante, el origen de un mito famoso, de un combate épico o el motivo de un cuadro célebre» (art. . $^{\circ}$ ). Dejando al margen la idea de paisaje, que vendría a complicar de forma innecesaria en este punto la aclaración de la relación entre memoria y espacio, parece obvio que los hechos de la memoria histórica pueden ser conceptuados como sucesos históricos. Pero la memoria histórica entendida como bien patrimonial lleva implícita una peculiar espacialidad aún pendiente de definir en toda su especificidad y para la que el legado de la historia y la praxis del patrimonio se revelan insuficientes. La geografía tiene mucho que decir a este respecto.

\subsection{Memoria histórica y espíritu del lugar}

En una concepción cercana al proyecto de Pierre NoRA (1997), la memoria histórica apila hechos $\mathrm{y}$, en consecuencia, sus lugares de referencia. Estos, recordados $\mathrm{u}$ olvidados por una sociedad $\mathrm{y}$, a menudo, como heridas mal cicatrizadas, adquieren periódica o esporádicamente nuevos significados y crean no pocos conflictos en su entendimiento, aceptación y reposición. Los lugares de memoria histórica tienen, cuando poseen reconocimiento legal, un marchamo que trata de objetivar sus valores y condiciones de tutela, pero estos valores no son fáciles de proyectar en el espacio. El concepto de espíritu del lugar puede ayudar.

2 Icomos, 1982: Jardines [y Sitios] históricos (Carta de Florencia 1981 [adoptada por Icomos en 1982, [en línea]. Disponible en: https://www.icomos.org/images/DOCUMENTS/Charters/gardens_sp.pdf [Consulta: 13/12/2019]. 
Concretado en una declaración del Icomos, ${ }^{3}$ esta figura aporta un enfoque que encaja con las claves de la memoria histórica, en las que los aspectos no tangibles asociados a hechos históricos que han dejado escasa huella en el espacio (aunque no siempre) son fundamentales para entender mejor unos hechos cuya memoria debe ser conservada con unas claves que no son las habituales en el resto del patrimonio.

Se entiende por espíritu del lugar:

[...] el conjunto de los elementos materiales (sitios, paisajes, construcciones, objetos) e inmateriales (memorias, relatos, ritos, festivales, conocimientos), físicos y espirituales que dan sentido, valor, emoción y misterio al lugar (ICOMOS, 2008).

Tómese nota de que las dos primeras referencias que la declaración destaca entre los elementos inmateriales son las memorias y los relatos, dos aspectos que entroncan directamente con la memoria histórica y que complementan la mirada espiritual que proporciona sentido, valor y emoción a estos lugares. En el mundo del patrimonio, existen publicaciones que aplican este concepto aún joven a determinados bienes patrimoniales (CAHN, 2008; TSENG et al., 2013), pero es prácticamente inexistente la producción que lo relaciona con lugares de memoria histórica (Montrusque-Bisso, 2016) y, cuando surge, es para alertar de su manipulación (RoIgé, 2016), ya que el espíritu de los lugares de la memoria histórica precisa de escenarios, pero nunca de reconstrucciones temáticas.

\section{LA MEMORIA HISTÓRICA EN EL MUNICIPIO DE SEVILLA}

\subsection{El contexto legal autonómico}

El reconocimiento oficial de los lugares de memoria histórica en Andalucía tiene como referencia dos textos legales ya citados: el Decreto 264/2011 que regulariza la creación de los Lugares de la Memoria Histórica y la Ley 2/2017 de Memoria Histórica y Democrática de Andalucía, que, entre otros aspectos, normaliza los Lugares de Memoria Democrática de Andalucía. El primero de ellos se justifica en «la necesidad de constatar los acontecimientos históricos acaecidos durante [... el franquismo] y [...] evitar que el paso del tiempo conlleve su olvido» (Preámbulo del decreto). Se definen como Lugares de Memoria Histórica de Andalucía aquellos vinculados «a hechos o acontecimientos singulares» acaecidos entre el golpe militar del 18 de julio de 1936 y la entrada en vigor de la Constitución Española el 29 de diciembre de 1978 (art. 2, punto 1).

Aunque el decreto no especifica claramente la naturaleza de esos hechos o acontecimientos singulares, se pretende que estos lugares «incentiven la identidad cultural de la comunidad, fortalezcan su sentido de pertenencia al territorio y sean parte constituyente del aprendizaje de nuestra herencia democrática» (ibidem, texto introductorio del decreto); todo ello parte de un mandato del

3 Icomos, 2008: Declaración de Quebec sobre el Espíritu del Lugar [en línea]. Disponible en: https:/ / icomos.es/wp-content/uploads/2020/01/13.DECLARACIÓN-DE-QUEBEC.pdf [Consulta:

21/10/2019]. 
Memoria Histórica y Patrimonio. Consideraciones conceptuales y metodológicas...

Estatuto de Autonomía de la comunidad andaluza. En el texto también aparece el reconocimiento a las víctimas del lado vencido como uno de los motivos clave que activan la aprobación del decreto. Su desarrollo se ha concretado en una cincuentena de Lugares de Memoria Histórica en Andalucía, cuatro de ellos en el municipio de Sevilla (ver más adelante). Estos lugares no poseen ninguna tutela patrimonial, pese a que su tramitación y consideración ya los acerque a una figura de protección.

No habían transcurrido seis años desde la promulgación del decreto cuando aparece la Ley 2/2017 de Memoria Histórica y Democrática de Andalucía. En ella, la Memoria Democrática se define como:

La salvaguarda, conocimiento y difusión de la historia de la lucha del pueblo andaluz por sus derechos y libertades para hacer efectivo el ejercicio del derecho individual y colectivo a conocer la verdad de lo acaecido en la lucha por los derechos y libertades democráticas (art. $4 .^{\circ}$, apartado a)

Se entiende pues que la historia democrática es una historia de lucha, lo que denota un sentido épico de la democracia que puede dar lugar a sectarismo al no incluir entre las víctimas, al menos como declaración de intenciones, a quienes padecieron violencia de manera injusta sin esa actitud proactiva, con independencia de su postura política. El período histórico que observa la ley se amplía, ya que incorpora todo el período republicano y la transición hasta la entrada en vigor del primer estatuto de autonomía andaluz (11 de enero de 1982).

La ley prevé la creación de un Inventario de Lugares de Memoria Democrática de Andalucía, sensiblemente diferentes de los Lugares que habían sido reconocidos por el Decreto 264/2011. En este caso, un Lugar de Memoria Democrática:

[...] es aquel espacio, inmueble o paraje que [...] revele interés [...] como patrimonio histórico [...] por haberse desarrollado en él hechos de [...] significación histórica, simbólica o por su repercusión en la memoria colectiva, vinculados con la lucha del pueblo andaluz por sus derechos y libertades democráticas (art. 21. ${ }^{\circ}$ ).

Cuando los Lugares de Memoria Democrática se estructuran uno a continuación de otro y comparten criterios de interpretación (por su relevancia histórica, paisajística, simbólica, ambiental, etnográfica o antropológica) pueden articularse en Senderos de Memoria Democrática de Andalucía (ibidem, art. 22).

Los Lugares son asumidos a la luz de la definición como patrimonio histórico y esto se refrenda en la incorporación de su inventario al más general Inventario de Bienes Reconocidos del Patrimonio Histórico Andaluz, regulado por la Ley 14/2007 del Patrimonio Histórico de Andalucía. Esto determina que su identificación y tutela han de equipararse, con sus especificidades, al del resto del patrimonio autonómico; proceso que no es ni será rápido ni sencillo. En el momento actual existen muy pocos Lugares de Memoria Democrática de Andalucía declarados: solo siete (tres en la provincia de Córdoba, uno en la de Cádiz, otro en la de Málaga y dos en la de Sevilla, aunque existen otros nueve incoados y otro del que ya se ha concluido la fase valorativa.

A estos Lugares hay que añadir 36 que están citados en el «Informe de seguimiento de las actuaciones en materia de memoria democrática 2017-2018» (Consejería de la Presidencia, Administración Local y Memoria Democrática, 2019). Se trata de propuestas que proceden de asociaciones, municipios, sindicatos 
y particulares. Aún no han sido incoadas, pero el hecho de estar recogidas en el informe oficial de la consejería evidencia la voluntad política, al menos cuando se publicó el informe, de impulsarlas en el futuro.

Por otro lado, hay que señalar casos sui generis como el lugar de fusilamiento de Blas Infante, declarado bien de interés cultural como sitio histórico por la Junta de Andalucía en mayo de 2011 y, a los pocos meses, en diciembre, Lugar de Memoria Histórica; o el edificio de la antigua Capitanía General de la Gavidia de Sevilla (hoy Consejería de Justicia), declarada bien de interés cultural en la categoría de monumento en mayo de 1974 (entonces monumento histórico-artístico) e incoado como Lugar de Memoria Democrática en enero de 2019). Se da la circunstancia de que, aunque este inmueble poseía valores arquitectónicos sobrados para ser declarado monumento, en cambio, la argumentación de sus valores destaca el hecho de haber sido un edificio clave en el triunfo del golpe militar del 18 de julio de 1936 e íntimamente relacionado con la figura del teniente-general Queipo de Llano y sus encendidas alocuciones radiofónicas.

Ambos espacios, en tanto que bienes de interés cultural, ya tienen el máximo nivel de protección. Cabe esperar de ello un problema de encaje en su tutela patrimonial, ya que, cuando el lugar de fusilamiento de Blas Infante se reconvierta de Lugar de Memoria Histórica a Lugar de Memoria Democrática y cuando se resuelva el proceso de incoación y, como es previsible, también se declare la Capitanía General de la Gavidia como Lugar de Memoria Democrática, pasarán ambos a incluirse en el Inventario de Lugares de Memoria Democrática, que a su vez forma parte, como se ha adelantado, del Inventario de Bienes Reconocidos del Patrimonio Histórico Andaluz (ver la subdivisión tipológica básica del Patrimonio Histórico Andaluz según la ley 14/2017 en Tabla 3). Sin embargo, dada su condición de bien de interés cultural, ya forman parte del Catálogo General del Patrimonio Histórico Andaluz y se trata de dos tipologías de registro, catálogo e inventario, excluyentes, ya que el segundo, de un valor jerárquico inferior, es concebido por la ley como complemento del primero, que es el patrimonio más valorado institucionalmente. Existe, en suma, un problema de compatibilidad y articulación entre ambas normas (la Ley del Patrimonio Histórico y la Ley de Memoria Histórica y Democrática); las contradicciones e implicaciones que de ello se derivan están aún por debatir y resolver.

No obstante, y regresando a la definición de los Lugares de Memoria Democrática de Andalucía, la consideración patrimonial está asegurada dado que el artículo 23 de la ley 2/2017 dispone que el Inventario de Lugares de Memoria Democrática de Andalucía será una sección del Inventario de Bienes Reconocidos del Patrimonio Histórico Andaluz; cuestión que, sintetizando el proceso, hace desembarcar la memoria histórica en el mundo del patrimonio, y no al revés. De ello se deduce que la administración cultural andaluza tendrá que tutelar unos bienes que, ni ha conceptuado ni creado, ni tiene experiencia previa en su gestión. Pero no solo es una cuestión de la Administración, la reflexión intelectual tampoco se ha caracterizado por su sensibilidad hacia estos campos. Baste señalar que, tal vez cerrando un ciclo justo antes de que la pandemia de la covid-19 lo trastocase todo, a finales de febrero y principio de marzo de 2020, la Asociación para la Interpretación del Patrimonio, que tan atenta ha estado en otros momentos a incorporar nuevos contenidos y miradas al patrimonio, en sus XIX jornadas tituladas La memoria de los lugares. La interpretación del patrimonio y el derecho al paisaje, los Lugares de la Memoria Histórica o Democrática no fueron 
Memoria Histórica y Patrimonio. Consideraciones conceptuales y metodológicas...

objeto de trabajo.

TABLA 3

Subdivisión básica del Patrimonio Histórico Andaluz según la ley 2/2007

\begin{tabular}{|c|c|c|}
\hline \multicolumn{3}{|c|}{ Patrimonio Histórico Andaluz } \\
\hline Tipos & $\begin{array}{l}\text { Catálogo General del Patrimonio } \\
\text { Histórico Andaluz }\end{array}$ & $\begin{array}{l}\text { Inventario de Bienes Reconocidos del } \\
\text { Patrimonio Histórico Andaluz }\end{array}$ \\
\hline Carácter & Patrimonio de primer rango institucional & \begin{tabular}{|l} 
Patrimonio de segundo rango y \\
complementario del Catálogo General
\end{tabular} \\
\hline Descripción & $\begin{array}{l}\text { «El Catálogo General [...] comprenderá } \\
\text { los Bienes de Interés Cultural, los bienes } \\
\text { de catalogación general y los incluidos } \\
\text { en el Inventario General de Bienes } \\
\text { Muebles del Patrimonio Histórico } \\
\text { Español» (art. 7, punto 1) }\end{array}$ & $\begin{array}{l}\text { «Este instrumento recogerá aquellos } \\
\text { bienes que [...] se identifican como } \\
\text { integrantes de nuestro Patrimonio } \\
\text { Histórico, contribuyendo, por tanto, a } \\
\text { su mayor conocimiento y al incremento } \\
\text { de la seguridad jurídica» (título II } \\
\text { de la Exposición de motivos) «[...] } \\
\text { correspondiendo a la Consejeria } \\
\text { competente en materia de patrimonio } \\
\text { histórico su formación, conservación y } \\
\text { difusión» (art. 13, punto 1). }\end{array}$ \\
\hline $\begin{array}{l}\text { Relación con } \\
\text { la memoria } \\
\text { histórica }\end{array}$ & $\begin{array}{l}\text { En principio sin relación, aunque se } \\
\text { generarán desajustes cuando en el } \\
\text { futuro existan lugares declarados bien } \\
\text { de interés cultural que, a su vez, formen } \\
\text { parte del Inventario de Lugares de } \\
\text { Memoria Democrática de Andalucía }\end{array}$ & $\begin{array}{l}\text { Incluye el Inventario de Lugares de } \\
\text { Memoria Democrática de Andalucía }\end{array}$ \\
\hline
\end{tabular}

Fuente: Elaboración propia.

\subsection{La memoria histórica reconocida en el municipio de Sevilla: la escala gene- ral de la ciudad}

El reconocimiento oficial de la memoria histórica en Sevilla es corto en número de lugares, aunque complejo en su comprensión (Tabla 4). Todos los lugares se proyectan en el espacio de manera puntual, con la excepción del caso particular de las fosas del cementerio de San Fernando, que es una pieza urbana de casi 28 ha; si bien las fosas ocupan una extensión mucho menor. Otra salvedad viene impuesta por el canal de los Presos, que más que un lugar es una sucesión de espacios articulados por el canal de irrigación construido por reclusos que, a cambio de su trabajo, redimían su condena. Posee una estructura lineal irregular que atraviesa el sector oriental y suroriental del municipio de Sevilla (aparte de otros del Bajo Guadalquivir). 
TABLA 4

Lugares de Memoria Histórica y Democrática de Sevilla

\begin{tabular}{|c|c|}
\hline Base legal o documental & Lugar \\
\hline \multirow{4}{*}{$\begin{array}{l}\text { Lugares de Memoria Histórica de } \\
\text { Andalucía (Decreto 264/2011) }\end{array}$} & Antigua Cárcel de Ranilla \\
\hline & Antigua Comisaria de Investigación y Vigilancia \\
\hline & Lugar del fusilamiento de Blas Infante \\
\hline & Canal de los Presos \\
\hline \multirow{3}{*}{$\begin{array}{l}\text { Lugares de Memoria Democrática } \\
\text { de Andalucía }\end{array}$} & Jefatura Superior de Policía de la Gavidia (incoado) \\
\hline & Cuartel o Capitanía General de la Gavidia (incoado) \\
\hline & $\begin{array}{l}\text { Lugar del asesinato de Francisco Rodríguez Ledesma } \\
\text { (incoado) }\end{array}$ \\
\hline \multirow{2}{*}{$\begin{array}{l}\text { Lugares de Memoria Democrática } \\
\text { de Andalucía («Informe de } \\
\text { Seguimiento de las Actuaciones } \\
\text { en Materia de Memoria Histórica } \\
\text { 2017-2018») }\end{array}$} & Fosas del cementerio de San Fernando (propuesto) \\
\hline & $\begin{array}{l}\text { Pintada del Movimiento Homosexual de Acción } \\
\text { Revolucionaria en los Juzgados del Prado de San Sebastián } \\
\text { (propuesto) }\end{array}$ \\
\hline
\end{tabular}

Fuente: Elaboración propia a partir de los documentos citados

En cuanto a los hechos históricos con los que se relacionan estos nueve Lugares, una buena parte está vinculada al golpe militar o sus meses posteriores (cuatro); dos con el franquismo; dos con la transición y uno que abarca los períodos de la Guerra Civil y el franquismo. Específicamente y diferenciando entre Lugares de Memoria Histórica, Lugares de Memoria Democrática y propuestas del «Informe de seguimiento de las actuaciones en materia de memoria histórica 2017-2018», los primeros (Decreto 264/2011) son cuatro y con gran dispersión (Mapa 1): Comisaría de Investigación y Vigilancia (centro), lugar de fusilamiento de Blas Infante (periferia noroeste), cárcel de Ranilla (Nervión) y el canal de Los Presos (sector oriental y suroriental del municipio de Sevilla).

Respecto de los Lugares de Memoria Democrática de Andalucía (Ley 2/2017), hay tres, solo uno de ellos ligado al propio levantamiento militar: Capitanía General (centro). Otro se relaciona con la represión franquista ya avanzada la dictadura: la Jefatura Superior de Policía de la Gavidia (en el centro también y muy próximo al anterior) y un tercero conectado con un hecho acaecido durante la transición: el sitio del atentado en el Cerro del Águila contra Francisco Rodríguez Ledesma (tiroteado en julio de 1977 y, como consecuencia de ello, fallecido en enero de 1978). 


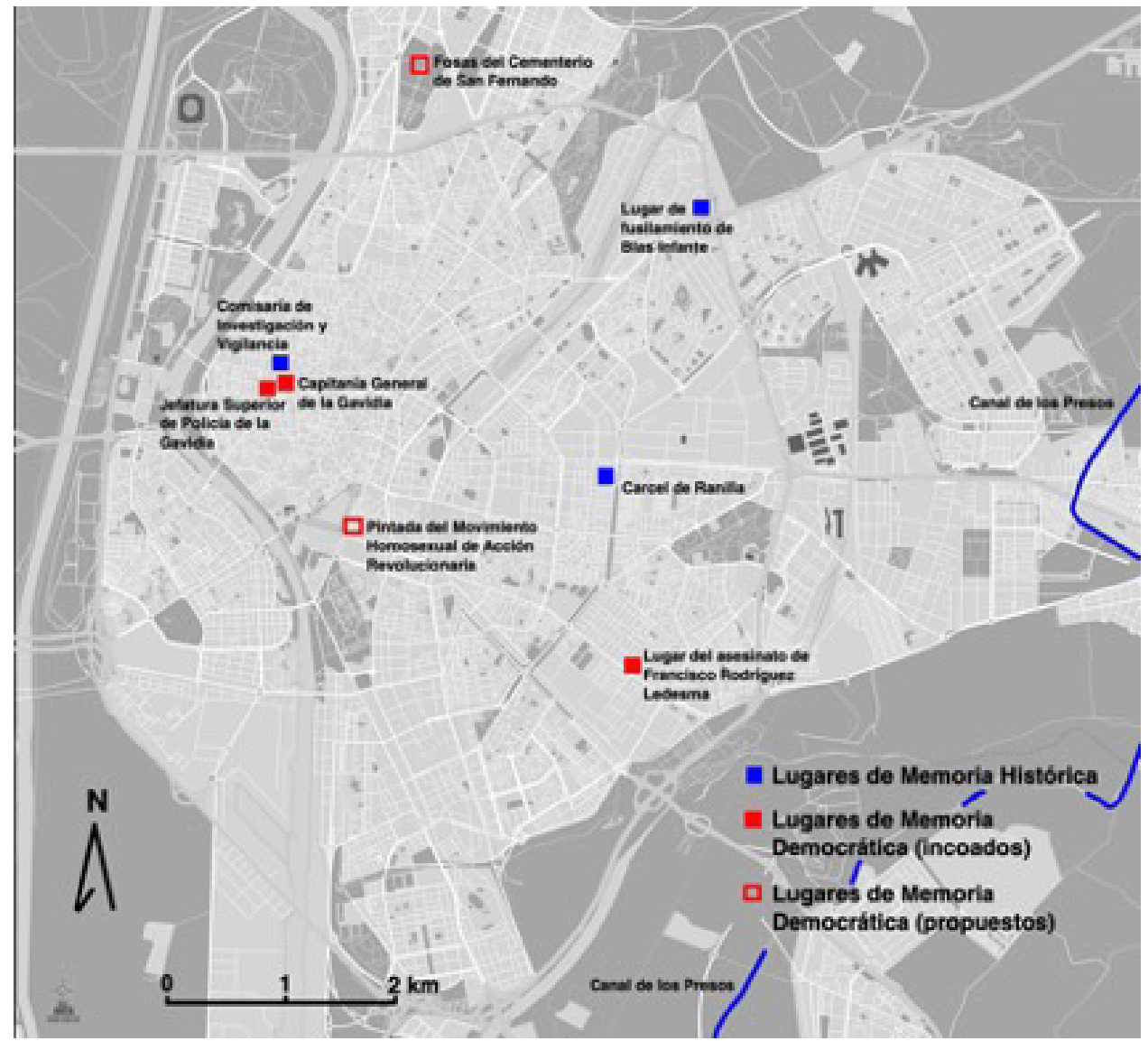

Mapa 1. La memoria histórica en Sevilla. Fuente: Elaboración propia tomando como base los Mapas Ilustrator de España

Existen otros dos lugares en el municipio de Sevilla que, sin haber sido incoados aún (y con la incertidumbre de que lleguen a serlo en un plazo medio) sí fueron incluidos en su día entre las 36 propuestas sociales para su declaración en el citado «Informe de seguimiento de las actuaciones en materia de memoria histórica 2017-2018». Se trata, por un lado, de una reivindicación de gran consenso entre las entidades memorialistas: las citadas fosas del cementerio de San Fernando, y, por otro, de una pintada realizada el 24 de junio de 1978, y conservada que es lo verdaderamente significativo, en los bajos de los Juzgados del Prado de San Sebastián por parte del Movimiento Homosexual de Acción Revolucionaria (Figura 1). 


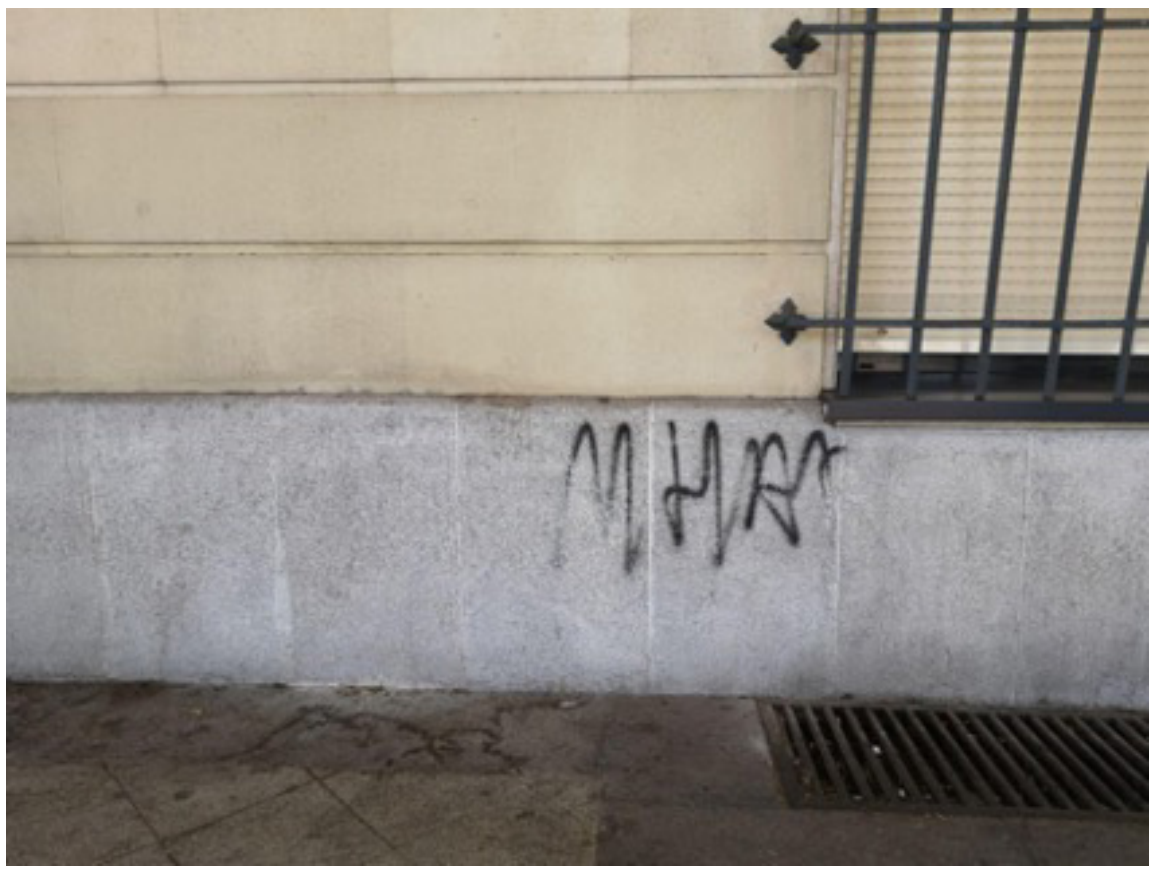

Figura 1. Pintada del Movimiento Homosexual de Acción Revolucionaria en los Juzgados del Prado de San Sebastián. Fuente: Elaboración propia, 2019.

En cuanto a la determinación de los escenarios de estos lugares, puede señalarse, a la luz del reconocimiento oficial, que tres de ellos (Capitanía General, Comisaría de Investigación y Vigilancia y Jefatura Superior de Policía de la Gavidia) conforman entre sí un escenario compartido (entorno de las plazas de la Gavidia y del Duque de la Victoria) en el que habría que incluir, al menos, otros dos espacios sin reconocimiento alguno en la actualidad (el antiguo Teatro Variedades y la plaza del Duque de la Victoria; ver más adelante). Los otros seis Lugares, por su modo de insertarse en la ciudad y de interrelacionarse con otros lugares de la memoria, serían escenarios individuales, si bien las fosas del cementerio de San Fernando, por su número, distribución y amplitud de sus recintos requieren un análisis más complejo en este escenario.

Tampoco debe pensarse que el antes aludido entorno de las plazas de la Gavidia y del Duque de la Victoria es el único escenario compartido en el municipio de Sevilla. Se ha dejado para publicaciones futuras la presentación y análisis más exhaustivos de estos escenarios compartidos. En todo caso, puede señalarse que, al menos, los entornos de la Plaza Nueva, Triana y las collaciones nororientales del antiguo sector intramuros (Ómnium Sanctórum, San Gil, San Marcos, etc.) conforman otros escenarios compartidos de notable significado memorialista. 


\subsection{La memoria histórica reconocida en el municipio de Sevilla: la escala espe- cífica de los lugares}

El conocimiento, y aún más el reconocimiento oficial, de los lugares de la memoria histórica en el municipio de Sevilla desde la perspectiva espacial todavía tiene un largo recorrido por hacer. Ya se han presentado en el apartado anterior los Lugares que desde el punto de vista institucional han sido objeto de alguna atención, pero, dada la importancia que el golpe militar tuvo en la ciudad, su lectura patrimonial está todavía por revelarse. Existen libros que dan cuenta de los espacios en los que se desarrollaron los hechos: algunos con un destacado análisis histórico (BRAOJOs et al., 1990; GiBSON, 1986; OrTIZ, 1988; SALAS, 1992); otros con una notable vocación cartográfica (HURTADO, 2011); no faltan las narraciones noveladas que reflejan la geografía urbana de la Sevilla de la Segunda República y el golpe militar (BURGOS, 1982; REY, 2004; SALAS, 1986), ni las visiones críticas que rescatan desde el siglo XXI extremos desconocidos o parcialmente interpretados (CARO, 2018; García Márquez, 2019). Específicamente sobre los lugares de memoria histórica en la ciudad hay que citar la obra coordinada por Rafael López Fernández (2014), un compendio poliédrico, algo asimétrico, pero muy bien cohesionado, y que estructura los lugares referidos al golpe militar, Guerra Civil y postguerra. Pero poca lectura patrimonial puede obtenerse de todas estas obras.

Ante la imposibilidad de identificar, valorar y diagnosticar los nueve Lugares de Memoria Histórica y sus escenarios, se opta por presentar dos que ejemplifiquen la virtualidad del método propuesto en este artículo: el lugar de fusilamiento de Blas Infante y la Jefatura Superior de Policía de la Gavidia.

\subsubsection{Lugar de fusilamiento de Blas Infante}

Este lugar se selecciona por ser uno de los espacios más conspicuos de Andalucía en relación con su memoria histórica y, al mismo tiempo, inserto en un escenario (individual), banalizado y distal (RIESCO, 2020). Allí fue asesinado un personaje sensible, proactivo e impulsor de la toma de conciencia como pueblo por parte de los andaluces más allá de las consignas románticas y folclóricas que impregnaban los tópicos regionales de principios del siglo xx (y que en parte continúan vivos en el XXI). El sitio en el que fue fusilado Blas Infante ha cambiado radicalmente desde la madrugada del 10 de agosto de 1936, pero, por encima de esto, apuntillado por el conjunto monumental construido por la Fundación Blas Infante, se ha conformado un ambiente trascendente que, más allá de los significados triviales de la publicidad y cartelería circundante, se arropa de la solemnidad y respeto que merece el recuerdo que supuso, al quitarle la vida a su promotor, el descabezamiento de una incipiente reivindicación de dignidad identitaria para los andaluces. 
TABLA 5

Ficha del lugar de fusilamiento de Blas Infante y su escenario de memoria histórica

\begin{tabular}{l}
\hline A) Nombre: Lugar de fusilamiento de Blas Infante \\
\hline B) Tipología: Espacio público \\
\hline C) Carácter del escenario en el que se inserta: \\
\hline D) Reconocimientos oficiales \\
a) Memorialista: Lugar de la Memoria Histórica de Andalucía (Decreto 264/2011) \\
b) Patrimonial no memorialista: Bien de interés cultural (sitio histórico) \\
c) Otros: -
\end{tabular}

E) Localización y emplazamiento:

a) Ubicación: plaza Gota de Leche, s/n

b) Emplazamiento

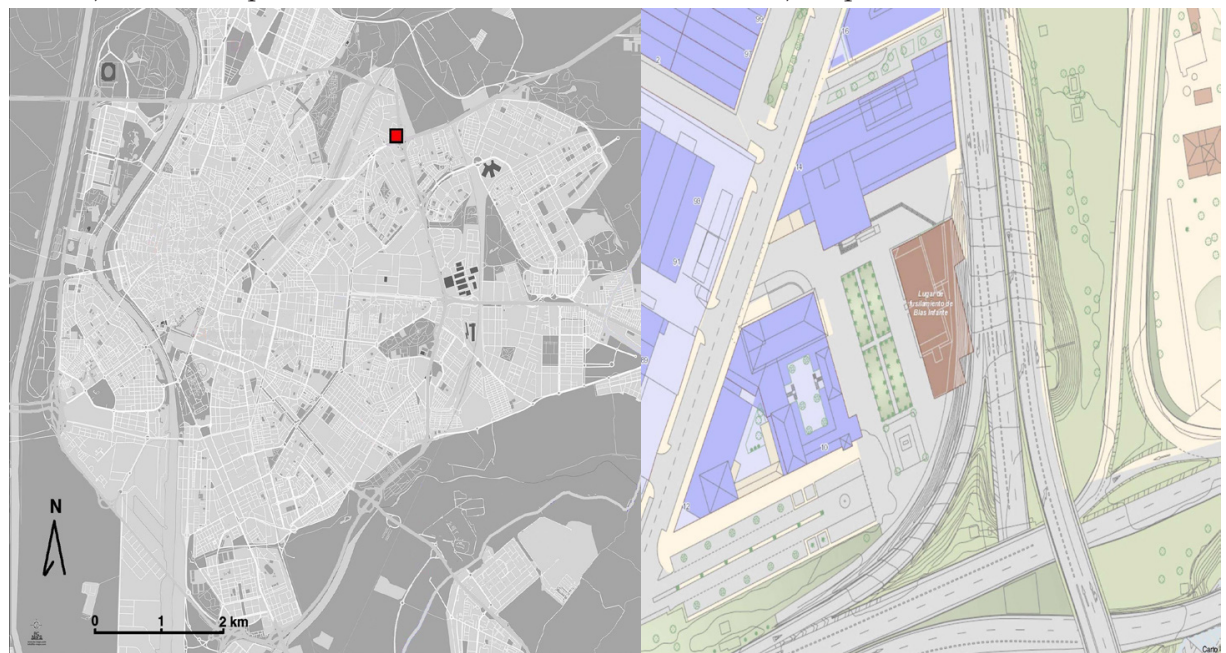

Fuente: Elaboración propia.

Fuente: IDE Sevilla

c) Vista oblicua

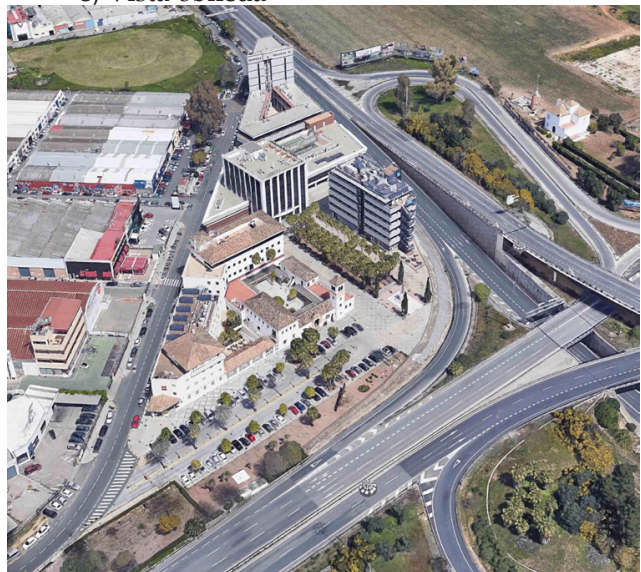

d) Fotografía:

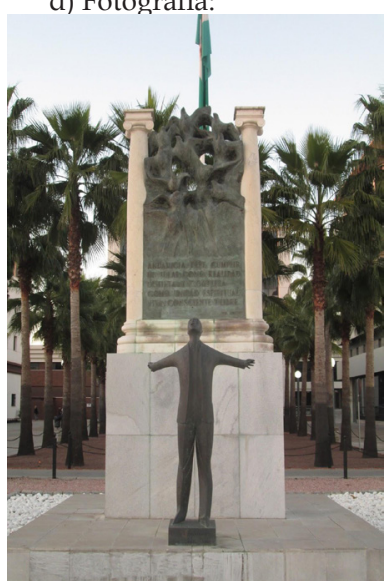

Fuente: Google Earth

Fte.: Blog de Roberto Paneque sobre cultura de Sevilla 


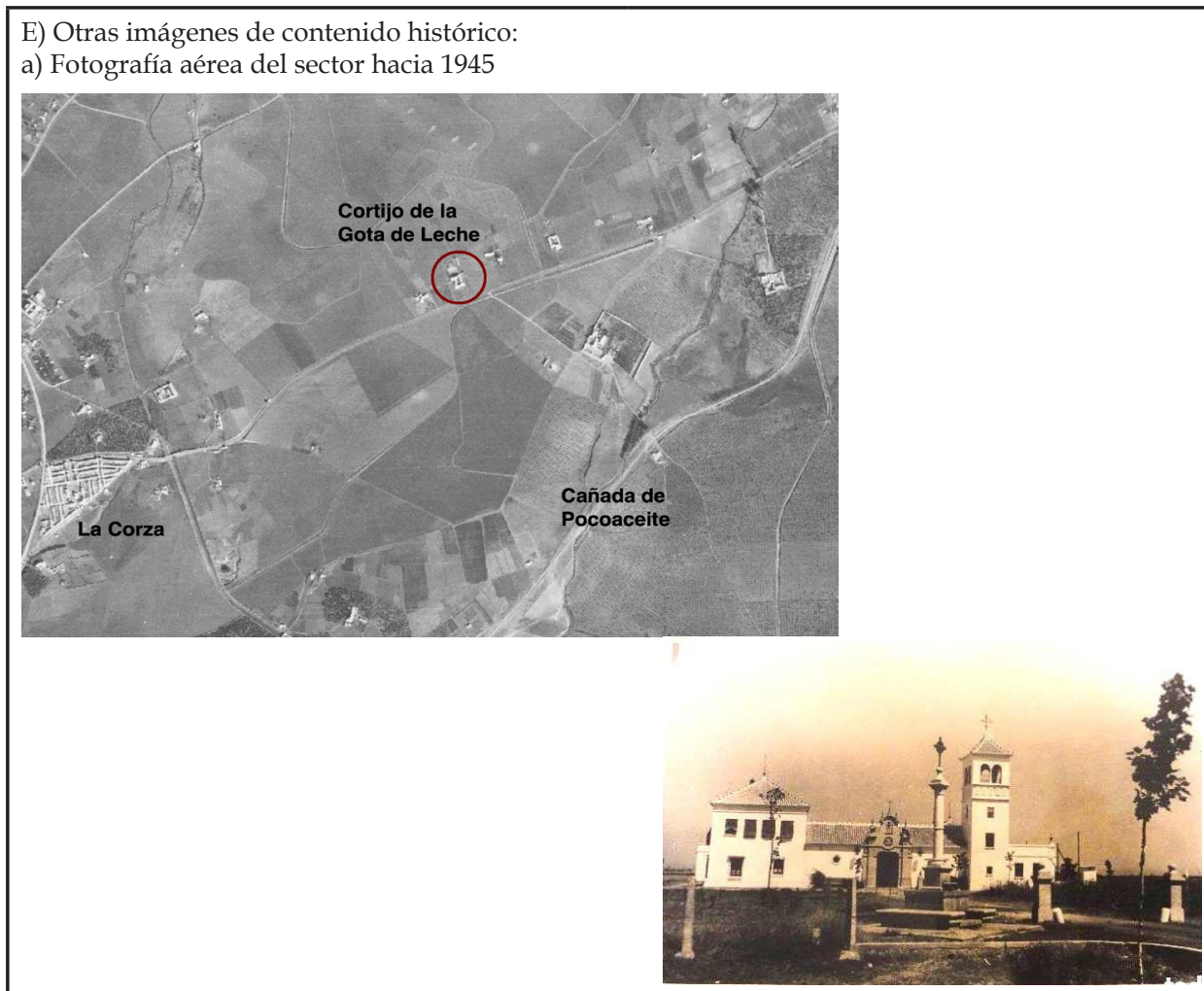

b) El cortijo de la Gota de Leche en 1929

F) Descripción general: El lugar de fusilamiento se encuentra en el extremo oriental del polígono industrial Calonge, más concretamente en el parque empresarial Morera y Vallejo, en uno de los principales accesos a Sevilla (junto la A-4). Aunque el antiguo cortijo se conserva, el entorno está denotado por edificios de oficinas de varias plantas construidos ya en el presente siglo. El hecho histórico se llevó a cabo en un lugar actualmente de acceso público y dispuesto en forma de dos plazas alargadas por los lados este y sur del antiguo cortijo.

G) Propiedad, función y gestión: La Fundación Blas Infante compró en los pasados años ochenta parte de los terrenos de las antiguas inmediaciones del cortijo con la intención de construir un monumento. La función es pública y la gestión corresponde al Ayuntamiento de Sevilla.

H) Inserción del lugar en el escenario de memoria histórica: Los muros laterales del antiguo cortijo, que fue profundamente renovado en 2007, desaparecieron en su práctica totalidad. Pero en su lateral asoma a un ámbito rectangular con palmeras y, en el extremo, al monumento a Blas Infante. Por el lado suroccidental, esta zona enlaza con otro espacio abierto cuadrangular frontal a la entrada principal del cortijo ocupado por aparcamientos con palmeras y naranjos. El conjunto está limitado, por la parte sur, por el punto en el que la avenida de Kansas City se conecta con la A-4 y, por el este, tras el hotel Ibis Budget, con la vía de circunvalación SE-30.

\section{EL ESCENARIO DE MEMORIA HISTÓRICA}

I) Nombre del escenario: Lugar de fusilamiento de Blas Infante (coincide por ser individual con el nombre del Lugar)

J) Tipo: Individual.

K) Carácter: Urbano 
L) Cambios operados desde el momento en que se relacionó con la memoria: La transformación ha sido muy profunda. El cortijo de la Gota de Leche, en el kilómetro 4 de la antigua carretera de Carmona, se encontraba en un espacio de fuerte carácter rural de cultivo de cereal a las afueras de Sevilla en 1936. Con la reorganización de los accesos a Sevilla prevista en el plan de 1946, que creó una nueva a entrada desde Madrid a través de la avenida de Kansas City, a la que se añade la creación de la SE-30 a partir de del plan general de 1987, el ámbito se ha convertido en un nodo de circulación (uno de los más importantes de Sevilla) y, también desde hace decenios, ha atraído la instalación del polígono industrial Calonge; aunque en este ámbito, por su visibilidad y facilidad de acceso desde las vías de comunicación ofrece sobre todo un espacio de oficinas y dos hoteles (pertenecientes a la misma firma). El cortijo se ha convertido en un lugar de celebraciones. En la actualidad, y debido a una inadecuada ordenación urbanística a partir de volúmenes inaceptables y usos cuestionables, el Lugar ha perdido, ya en el siglo XXI, la ocasión de mantener con mayor integridad la solemnidad que debió haber conservado.

M) Hitos y otros elementos destacados: El hito más destacado es el complejo monumental de los escultores José Ferrari (proyecto original) y de Sebastián Santos Calero, además del arquitecto Juan Escribano. En el paisaje también destacan los cuatro cipreses que rodean el complejo monumental, la torre del cortijo y el mástil, en el momento que tiene la bandera izada, también junto al complejo monumental citado. En el escenario también tiene gran protagonismo la cartelería y anuncios de los hoteles (Ibis Budget e Ibis Hotel), además de los tres carteles alusivos a estos hoteles.

N) Ambientación urbana: El carácter poco acogedor del sector y su compleja accesibilidad impiden que se convierta en un escenario atractivo para la población, por lo que permanece casi siempre solitario. La excepción la constituyen los actos que cada 10 de agosto se realizan en recuerdo de la figura de Blas Infante. 
Memoria Histórica y Patrimonio. Consideraciones conceptuales y metodológicas...

Ñ) Percepciones-cualificación del escenario:

a) Sociales:

«En el año del suceso [1936] el lugar formaba parte de un ámbito rural próximo a la ciudad de Sevilla, donde se ubicaba el cortijo perteneciente a la institución benéfica Consultorio de Niños de Pecho y Gota de Leche. Este inmueble de estilo regionalista, que aún se conserva, fue proyectado por Vicente Traver en torno a 1930.

Hoy, junto al cortijo restaurado podemos ver el monumento que se le realizó hace pocos años y la columna con la cruz que hace de plaza pública para los visitantes. Es una cruz de hierro forjado con decoración de roleos. Se levanta sobre una columna de mármol rematada con capitel. Se eleva sobre un pódium de piedra.»

Juan Manuel Jiménez (2011), Sevilla Dayly Photo [http:/ / sevilladailyphoto.blogspot. com/2011/08/la-cruz-del-cortijo-la-gota-de-leche.html

b) Experienciales y creativas:

Los lugares no son inocentes. En las tierras del Cortijo de Hernán Cebolla «[...] vuelve a repetirse la madrugada del 10 al 11 de agosto de 1936. Pronto sonarán las balas. Por un momento, el ruido pavoroso hará que callen los grillos de la noche calurosa. Luego, el silencio. Un silencio muy largo que se extenderá durante meses, años, décadas.

Aquí, en este lugar, aparentemente un cruce de carreteras en la salida de la ciudad, la memoria regresa como en un bucle infinito $[\ldots] »$.

Eva Díaz Pérez. La saca de la venganza (2014: 96)

«[...] Aquella madrugada de agosto

junto a la carretera de Carmona

cuando impunemente te fusilaron,

acabaron contigo ¡sí!

pero no pudieron con tu legado.

Porque no se aniquila un sentimiento,

una forma de entender el mundo.

Porque no se puede matar a un pueblo

¡Ave, Blas Infante!»

Réquiem por Blas Infante

Pepe Cesto Oliva (2011) [http:/ / pepecesto.blogspot.com/2014/08/requiem-por-blas-infante.html]

«[...] El 11 de madrugada, entre Sevilla y Carmona,

y el huerto de las Clarisas,

un torpe bando de guerra ha matado Andalucía.

Las esperanzas del pueblo

de aquel 18 de Julio solo recuerdan silencios.

Blas Infante, ya en el alba, sigue creciendo en las voces

y se hace clavel de luz»

Momentos. Poema. Nahuel Santana (2006)

[http://universoandalucista.blogspot.com/2010/01/ poema-remitido-por-su-autor-al-correo.

html] 


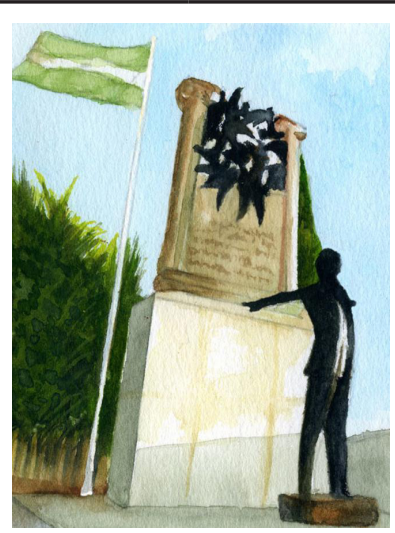

Recreación del lugar del fusilamiento de Blas Infante. Junta de Andalucía. Fuente: La Vanguardia [https:// www.lavanguardia.com/local/sevilla/20200227/473805026726/cuatro-decadasautonomia-andalucia-arrancada-pueblo.html]

O) Determinación sintética del espíritu del lugar: En el sitio concurren un hecho histórico (un fusilamiento sumarísimo) y un protagonista (el principal referente histórico del nacionalismo andaluz, Blas Infante) asesinado también en una fecha especial (en la madrugada del cuarto aniversario del levantamiento del General Sanjurjo o Sanjurjada). El atentado contra Blas Infante es, además de una afrenta al personaje histórico, un cercenamiento del proceso de empoderamiento identitario de Andalucía más allá de sus tópicos y basado en las raíces profundas de su cultura. Aunque el escenario ha cambiado casi por completo desde el momento de los hechos históricos que se conmemoran y es hoy un espacio anodino, está profundamente connotado como uno de los lugares (solo comparado por el barranco de Víznar en el que fue fusilado Federico García Lorca) en los que se encarna el lado más triste de la derrota social y cultural que supuso el levantamiento militar de julio de 1936.

P) Propuesta de delimitación del escenario y medidas que mejoren sus potenciales:

a) Propuesta de delimitación del escenario

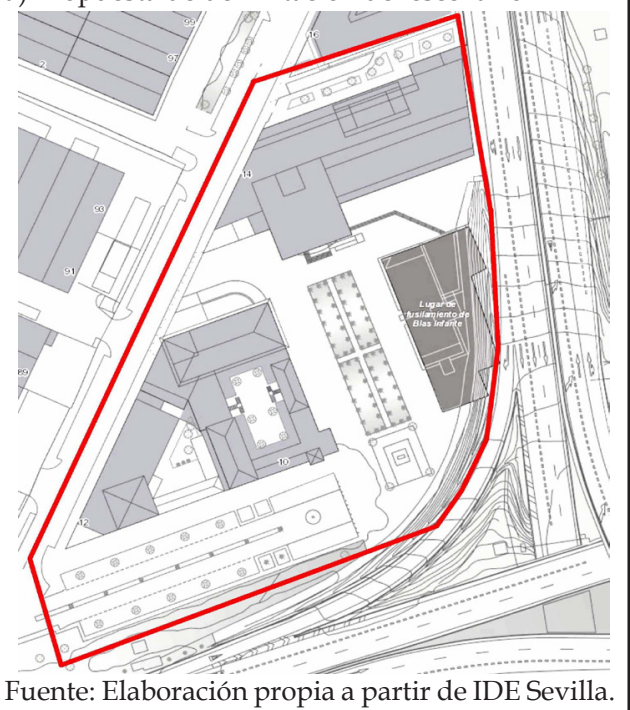

b) Medidas propuestas

- Mejorar el conocimiento de este escenario de la memoria histórica a todos los niveles de difusión. Esto incluye, desde la inclusión de cartelería para indicar su acceso desde las vías principales a la divulgación por medios de comunicación, educativos, etcétera que expandan lo que aquí aconteció.

- Tratar de recuperar la memoria de los muros desaparecidos del cortijo mediante signos en el espacio público que den idea del escenario original en el que se produjo el asesinato de Blas Infante.

- Aminorar la presencia de signos y carteles de empresas y publicidad que empequeñecen el sentido y simbología del lugar.

- Mantener la bandera andaluza de continuo sobre el mástil junto al complejo monumental.

Fuente: Elaboración propia de los autores. 


\subsubsection{Jefatura Superior de Policía de la Gavidia}

Este segundo caso de estudio se ha seleccionado, al contrario que el caso anterior, por tratarse de un edificio perteneciente a un tiempo más avanzado del franquismo, abandonado e incomprendido en su estilo y con expectativas de convertirse en un hotel más de la ciudad; todo ello en un entorno, el corazón del centro histórico, en el que los reconocimientos patrimoniales (institucionales e identitarios) rodean e impregnan su escenario. Este es compartido con otros lugares de memoria histórica por encontrarse en uno de los nodos principales del golpe militar del 18 de julio de 1936; ello lo convierte en un lugar bastante más complejo que el anterior (Tabla 6).

La antigua jefatura policial, amén de su ubicación sobre el desaparecido cuartel del Regimiento de Infantería San Hermenegildo, aporta al escenario en el que se inserta, más allá de los recuerdos del edificio al que sustituyó, los valores de la memoria de la etapa del desarrollismo, cuando en esta jefatura se reprimió y represalió a muchos sevillanos que militando o simpatizando con grupos clandestinos luchaban por volver a un régimen democrático. La determinación global de este escenario debería completarse con las fichas de, al menos, los otros tres edificios memorialistas cercanos (los antiguos Comisaría de Investigación y Vigilancia, Capitanía General de la División II y Teatro Variedades -que actuó como lugar de reclusión-), amén de la propia plaza del Duque, en la que se leyó por primera vez el bando de guerra por parte de los militares insurrectos.

TABLA 6

Ficha de la Jefatura Superior de Policía de la Gavidia y su escenario de memoria histórica

1. EL LUGAR DE MEMORIA HISTÓRICA

A) Nombre del lugar: Jefatura Superior de Policía de la Gavidia

B) Tipología: Dotacional de seguridad

C) Reconocimientos oficiales:

a) Memorialista: Lugar de la Memoria Democrática de Andalucía (Ley 17/2017).

b) Patrimonial no memorialista: Incluida en el Catálogo General del Patrimonio Histórico Andaluz (BOJA 19 de diciembre de 2007).

c) Otros: Incluido en el registro del Docomomo Ibérico 
E) Localización y emplazamiento:

a) Ubicación: plaza de la Gavidia, 2

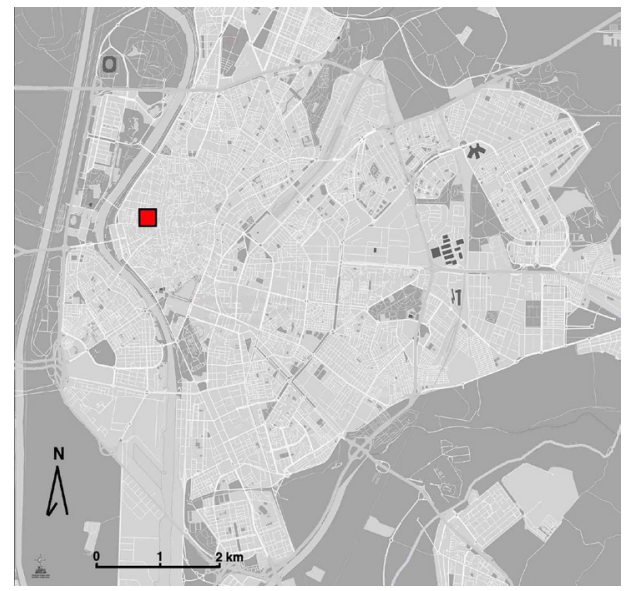

Fuente: Elaboración propia.

c) Vista oblicua

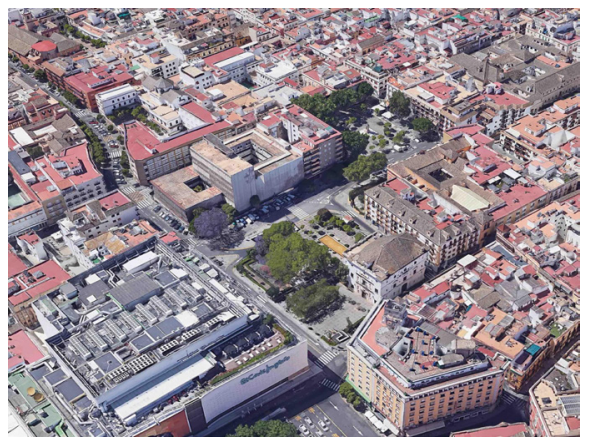

Foto: Google Earth

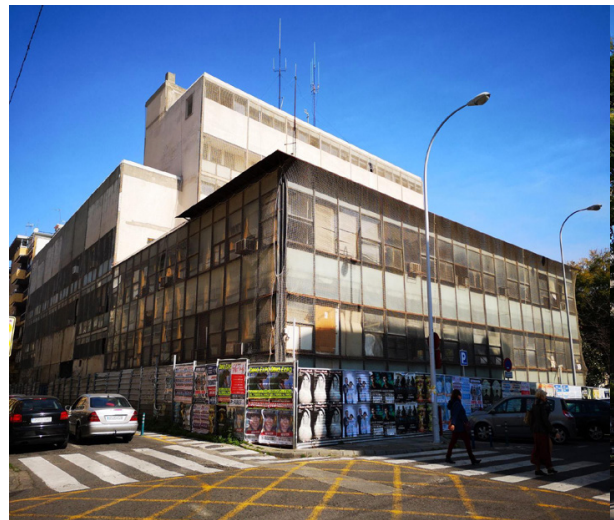

Foto: Los autores (febrero de 2020) b) Emplazamiento

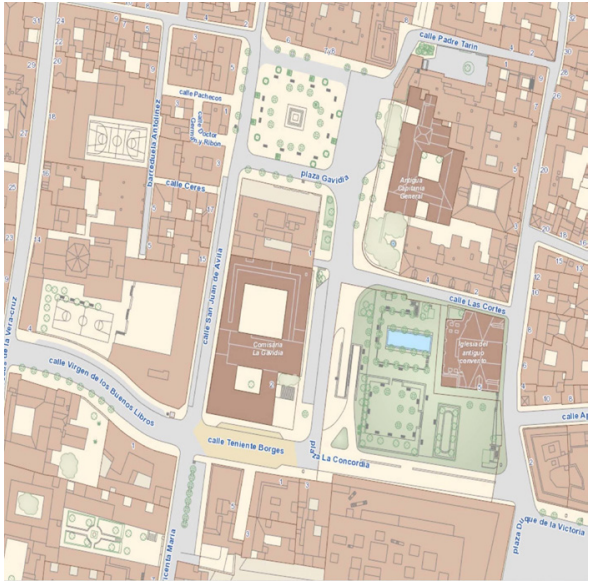

Fuente: IDE Sevilla

d) Fotografía:

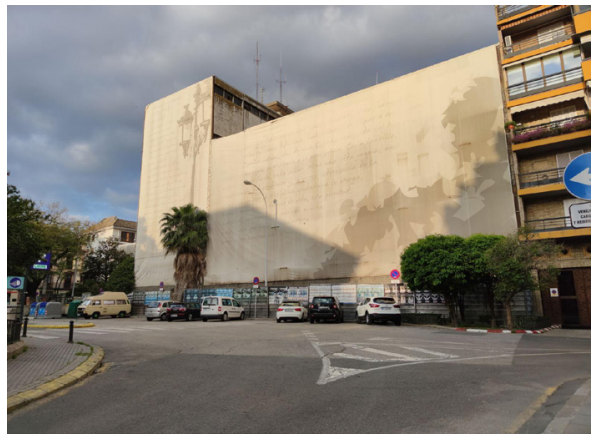

Foto: Los autores (marzo de 2020)

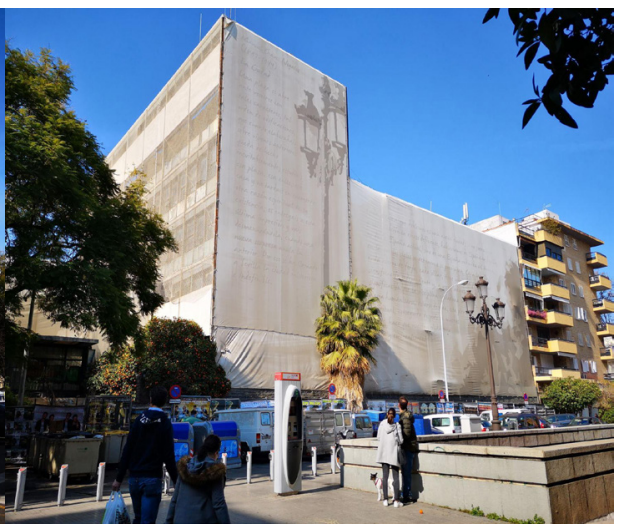

Foto: Los autores (marzo de 2019) 
E) Otras imágenes de contenido histórico:

a) El edificio a principios de los años sesenta

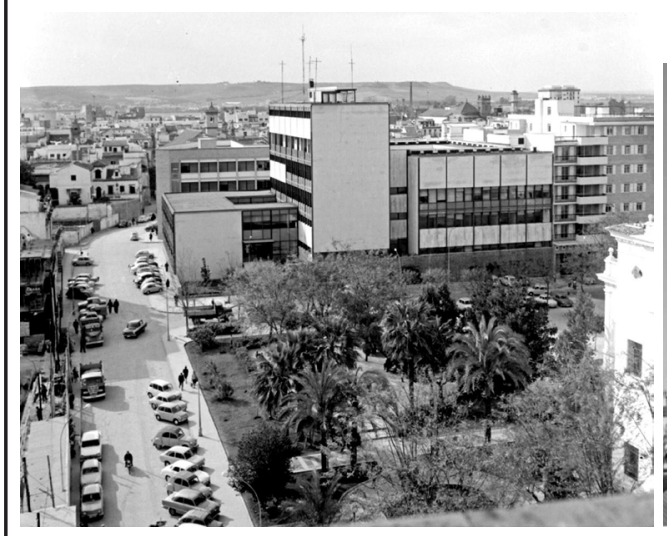

b) El edificio a principios de los años sesenta

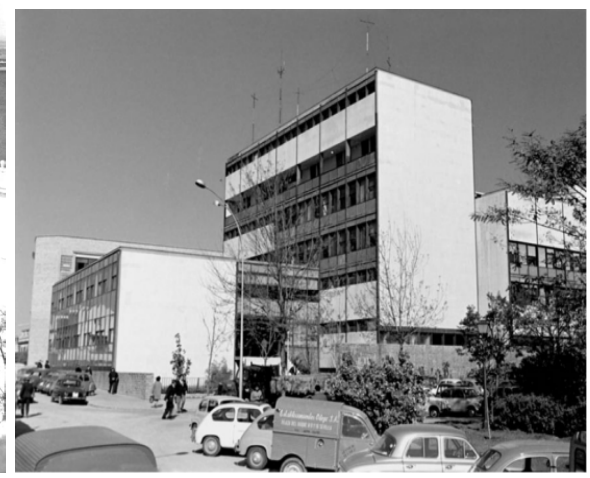

Fotos: Fototeca Municipal de Sevilla, fondo Cubiles

F) Descripción general: La antigua Comisaría o Jefatura Superior de la Gavidia fue construida en 1962 con arreglo al arquitecto Ramón Montserrat Ballesté. Se trata de un edificio de unos $7.500 \mathrm{~m}^{2}$ construido bajo el paradigma arquitectónico del Movimiento Moderno.

G) Propiedad, función y gestión: El edificio, antes perteneciente a la Policía Nacional, fue adquirido en 2006 por el Ayuntamiento de Sevilla con el objetivo actual de venderlo. El inmueble permanece sin uso desde 2003. En 2020 se habla de darle un uso hostelero, aunque compatibilizándolo con su papel de testimonio de la memoria histórica.

H) Inserción del lugar en el escenario de memoria histórica: La antigua jefatura policial se inserta en el entramado del corazón del intramuros de Sevilla, justamente en el ámbito en el que se desarrolla el tejido de carácter cuadrangular que caracteriza el sector noroccidental del casco histórico. El escenario viene estructurado fundamentalmente por tres plazas que se conectan como tres casillas de damero en diagonal: Gavidia, Concordia y Duque de la Victoria, a las que podría añadirse La Campana. La jefatura abre su entrada principal y escalinata a la plaza de la Concordia, imponiéndose así a una de las últimas operaciones de reforma interior de gran calado en la ciudad. El resto del entramado viene compuesto por la presencia de edificios de volúmenes contrastados y no bien integrados entre sí: grandes almacenes, tanto en la propia plaza de la Concordia, como en la próxima del Duque, hoteles, locales comerciales, bares y restaurantes.

\section{EL ESCENARIO DE MEMORIA HISTÓRICA}

I) Nombre del escenario: Entorno de las plazas de la Gavidia y Duque de la Victoria

J) Tipo: Compartido.

K) Carácter: Urbano

L) Cambios operados desde el momento en que se relacionó con la memoria: La propia creación de la jefatura de policía está ligada al proceso de transformación profunda de este sector iniciado a finales de los años cincuenta del siglo pasado. El derribo del antiguo cuartel de San Hermenegildo propició la creación de una plaza (de la Concordia) con aparcamiento subterráneo, la construcción de varios inmuebles de nueva planta y la edificación y apertura ya en la segunda mitad de los años sesenta de El Corte Inglés, constituyéndose en uno de los escaparates de la modernidad del franquismo tecnocrático y desarrollista. Después, durante más de medio siglo, su morfología ha tenido algunos cambios, pero secundarios. 
M) Hitos y otros elementos destacados: La jefatura de policía, por disposición y volúmenes, se convierte en un hito importante del sector, pero no en el principal, ya que compite con el edificio de El Corte Inglés, al que su altura y publicidad (acrecentada en determinadas épocas del año) confieren mayor protagonismo, tanto de la plaza de la Concordia como, sobre todo, de la del Duque de la Victoria. Otro hito significativo es la antigua capilla del cuartel de San Hermenegildo (actualmente vacía y que, entre otros usos, fue sede del Parlamento de Andalucía), conservada en contra del parecer del cabildo municipal de la época en un rincón de la plaza abierta. En la vecina plaza de la Gavidia, y perceptible desde la de la Concordia, la estatua de Luis Daoíz, obra de Antonio Susillo, también actúa como hito.

N) Ambientación urbana: Los espacios abiertos próximos a la antigua comisaría son de propiedad municipal; con uso local y vecinal en la plaza de la Gavidia, de recreo pese a su diseño incómodo y poco funcional en la de la Concordia y comercial (mercadillo), de descanso y de transporte público en la del Duque (taxis y autobuses urbanos y turísticos). El espacio adquiere metafunciones en momentos especiales del año: fundamentalmente durante las navidades por la presencia de decoración, alumbrado y el movimiento en los grandes almacenes y comercio próximo y, también, durante la Semana Santa por su proximidad al inicio de la carrera oficial, lo que hace que allí confluya un gran número de cofradías y público. En la plaza de la Gavidia, y relacionada con la figura de Luis Daoíz, que nació aquí en 1767, se realizan actos conmemorativos a la guerra de la Independencia cada 2 de mayo. El ambiente del sector se transforma durante los días festivos, cuando se reconvierte en tranquilo y local, con poca presencia humana en la plaza de la Concordia y en la del Duque, y más en la de la Gavidia en razón de sus locales de restauración y ocio. 
Memoria Histórica y Patrimonio. Consideraciones conceptuales y metodológicas...

N) Percepciones-cualificación del escenario:

a) Sociales:

«[A su entorno] tan delicado, el edificio responde con un juego de alturas y fachadas, un juego que, en su variedad, interpreta, sin concesiones pero de manera inteligente, la multiplicidad de escalas y texturas que caracterizan los centros históricos de las ciudades. Especial relevancia se le concede a la fachada de la plaza, donde se ubica el acceso principal al edificio y se concentran los aspectos más monumentales y representativos del mismo [...]».

Carlos García Vázquez (s.f.). Fundación Do.co.mo.mo Ibérico [http:/ / docomomoiberico.com

«Cuando apareció el edificio, provocó un rechazo tremendo, que en buena parte continúa [...]. En los primera mitad de los años cincuenta, en mis años de formación en la Escuela de Arquitectura de Barcelona, [...] descubrimos la arquitectura del Movimiento Moderno y nos empapamos de su lenguaje y estética. [...] cuando recibí el encargo de hacer una nueva Jefatura de Policía en el solar resultante de la demolición del Cuartel de San Hermenegildo, con indicación por parte de la propiedad de que fuera un edificio «abierto y moderno» [...] consideré que era una buena oportunidad para hacerlo. Algo que estuviera en consonancia con lo que se empezaba a realizar en las más importantes ciudades españolas, europeas y americanas. [...] Me había equivocado. La acogida en Sevilla no fue la que yo esperaba».

Ramón Montserrat Ballesté. El edificio de la Gavidia de Sevilla; un rechazo que no imaginé, ABC de Sevilla, 4 de octubre de 2015.

«Defendemos el valor de la memoria histórica de este espacio, por donde pasaron centenares de mujeres y hombres antifranquistas que fueron torturados por el solo hecho de defender los valores democráticos en plena dictadura franquista. Por ello, este edificio debe albergar -entre otros usos públicos- un espacio digno que recuerde un pasado negro y cruel de la reciente historia de la ciudad, para crear conciencia democrática entre las nuevas generaciones de jóvenes»

¿Están en contra de la privatización de la antigua comisaría de policía? ¿Qué piensan hacer al respecto? Osoigo.com

b) Experienciales y creativas:

La memoria de los centros de tortura del franquismo tiene nombre en Sevilla: comisaría de la Gavidia. Entre el «silencio sepulcral» de esos muros se hizo tangible «la lucha por la libertad», dicen sus testigos. Como la red de pasillos coronados por siniestros calabozos. Son los intestinos de un edificio abandonado y sobre cuyo uso futuro está abierto el debate en la ciudad. [...] «Al salir de la fábrica nos meten en un coche con dos policías y nos llevan camino a edificio policial», cuenta María del Carmen Vázquez, trabajadora del textil detenida por su actividad sindical. El trayecto conduce a un sótano y a «una celda muy fría, muy oscura». En aquellos siniestros calabozos explotan las sensaciones. [...] «Es un pasillo sin salida con tres calabozos pequeños que se conservan. Una piedra para dormir. Silencio sepulcral. Totalmente aislado en esta celda bastante sucia generalmente», explicaba el histórico sindicalista Eduardo Saborido [...]. La Gavidia es «un sitio absolutamente emblemático para la gente que ha luchado», dice Kechu Aramburu.

Juan Miguel Baquero, Comisaría de la Gavidia: la memoria del centro de tortura franquista. El Diario.es, 18 de enero de 2018.

«Cuando se fueron [los policías], mi padre [Plácido Fernández Viagas] y yo [Plácido Fernández hijo] tomamos un taxi, llegamos a la comisaría de la Gavidia y me estaban esperando [...]. Fueron días de interrogatorios continuos y yo, con dieciocho años, negando la pertenencia al partido [comunista...]. Como además no me pegaban, tampoco fue tan difícil... Emotivo sí, porque la primera Nochebuena que pasé solo, la pasé entre rejas. [...] Me dejaban muchas horas solo, para que me desmoronara, y cuando me subían a las oficinas para declarar, me traían a compañeros de la universidad que habían confesado, los ponían frente a mí y me delataban, pero yo seguía negando». Antoni Batista. La Carta. Historia de un comisario franquista, Madrid, 2010. 


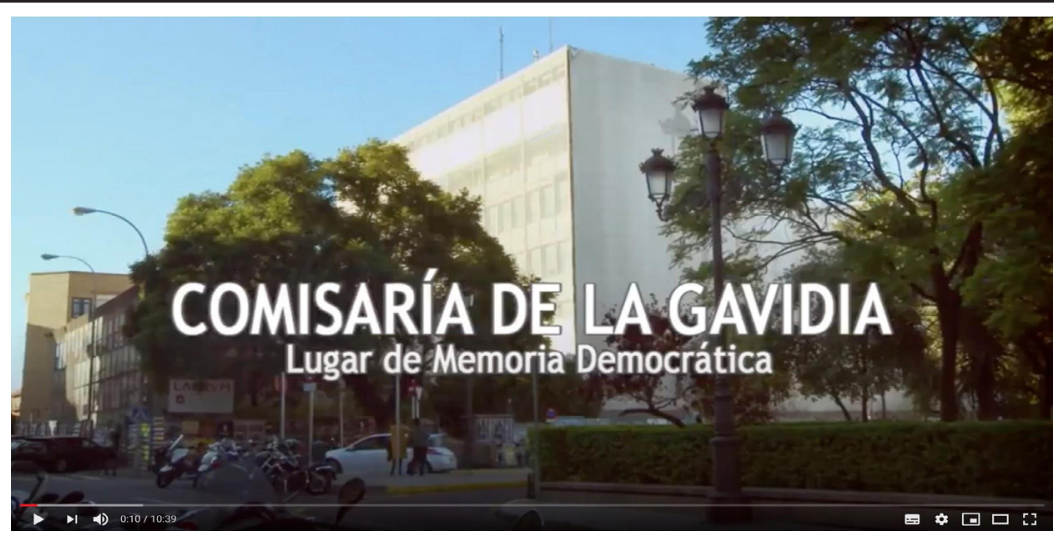

Documental Comisaría de la Gavidia. Lugar de Memoria Democrática. Fuente: Youtube, https:/ / www.youtube.com/watch?v=QS-MMILGae8 [Consulta: 22/10/2020]

O) Determinación sintética del espíritu del lugar: En la aportación de la antigua Jefatura Superior de Policía al espíritu del lugar del entorno de las plazas de la Gavidia y del Duque de la Victoria, hay que considerar que este inmueble es heredero del espacio que ocupaba el cuartel del Regimiento de Infantería San Hermenegildo o Soria 9, que fue uno de los espacios desde los que se condujo el golpe militar de julio de 1936. Su forma arquitectónica ligada al movimiento moderno, contrastada con las claves arquitectónicas de la zona (y de todo el centro histórico en general), introduce el progresista lenguaje de la modernidad arquitectónica del momento en que se construyó (1964) asumido paradójicamente por un cuerpo de policía dictatorial que hizo de este edificio un centro de detención y represión. El espíritu del lugar está fuertemente impregnado por la denotación y connotación de un inmueble que fue autista en el pasado (por su lenguaje arquitectónico incomprendido y descontextualizado y por su función) y que sigue siéndolo hoy (sin valoración social de sus formas y, sobre todo, por su languidecer sin uso y por la ausencia de un proyecto justo que tenga en cuenta sus valores arquitectónicos y memorialistas).

J) Propuesta de delimitación del escenario y medidas que mejoren sus potenciales: El escenario urbano que se propone para este lugar sería compartido

a) Propuesta de delimitación

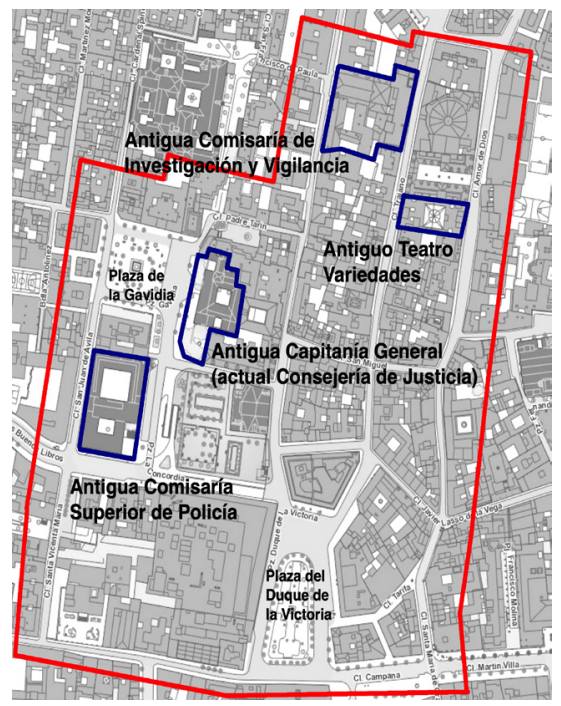


Memoria Histórica y Patrimonio. Consideraciones conceptuales y metodológicas...

b) Medidas propuestas:

- Recuperar el antiguo edificio de la Jefatura Superior de Policía de la Gavidia con un programa de funciones compatible con su condición de Lugar de Memoria Democrática. Entre estos usos han de estar el de museización de su lectura histórica y el de su pertenencia al Movimiento Moderno

- Integrar la aportación a la memoria histórica de este edificio de forma interrelacionada con otros lugares de memoria de este escenario, que fue uno de los nodos fundamentales del golpe militar

- Potenciar la relación de este solar con el antiguo Cuartel del Regimiento de Infantería de San Hermenegildo al que perteneció. También hay que estructurar la línea discursiva memorialista entre edificio, plaza y capilla (que fue sede de Las Cortes españolas entre el 23 abril y el 11 de junio de 1823 y Parlamento de Andalucía entre el 3 de diciembre de 1985 y el 27 de febrero de 1992).

Fuente: Elaboración propia de los autores.

\section{CONCLUSIONES}

En los últimos años se ha avanzado en la identificación global de los objetos de la memoria histórica, especialmente respecto a sus lugares. Sin embargo, la relación o puente entre memoria histórica y patrimonio dista de ser madura. Esta relación es todavía, a partir de las publicaciones científicas y ejemplos específicos de activación, difusa, incipiente y sin la profundidad que requeriría. No existen métodos, ni objetivos claros compartidos entre autores $y$, aunque es una reivindicación de las organizaciones memorialistas, aún falta un corpus teórico firme y una praxis exitosa que permitan afirmar que se está produciendo un entendimiento común entre la memoria histórica, incluyendo sus lugares, y el resto de los bienes patrimoniales. Se trata de un esfuerzo que ha de ser acometido de forma simultánea entre aquellos que proponen desde la base social los reconocimientos patrimoniales de esta memoria y los responsables de la tutela patrimonial. Hasta ahora, en comunidades como Andalucía, puede decirse que el mundo de la memoria histórica ha desembarcado en el puerto del patrimonio, pero también que en este puerto no se sabe muy bien (ni tampoco se ha expresado la voluntad firme de hacerlo) cómo operar con estos bienes y convertirlos en bienes de provecho social. Al respecto, en este artículo se han esbozado algunas claves para la interiorización de la memoria histórica en el mundo del patrimonio a través de los procesos de patrimonializacion. También se ha podido profundizar sobre las oportunidades que ofrece el concepto de espíritu del lugar para el análisis y prospectivas de estos espacios. Ello ha permitido recalar en algunas contradicciones resultantes de la difícil conjugación entre patrimonialización de base social (propia de las asociaciones memorialistas) y patrimonialización institucional (inherente a las declaraciones llevadas a cabo por la Administración).

Estos reconocimientos, relativamente recientes en su trayectoria en Andalucía (ni siquiera un decenio), parten de un concepto relacionado con la conmemoración, pero sin tutela patrimonial: los Lugares de la Memoria Histórica de Andalucía del Decreto 264/2011; y terminan derivando hacia esa tutela con la creación de los Lugares de Memoria Democrática fruto de Ley de la Memoria Histórica y Democrática de Andalucía 2/2017. Esta deriva, que proviene del mundo de la memoria y no del patrimonio, genera dudas de todo tipo por cuanto 
que traslada a la administración cultural la responsabilidad de la tutela (aunque sea compartida con las instituciones locales) en unas condiciones lejos del buen entendimiento común entre los lenguajes memorialistas y los patrimonialistas. Más específicamente, sin haber reconvertido aún la cincuentena de Lugares de Memoria Histórica del Decreto 264/2011 y sin haber solucionado el panorama exiguo y desajustado de siete lugares de Memoria Democrática declarados, más seis incoados y uno con la fase previa valorativa concluida. En otras palabras, un pequeño maremágnum que no sería tal si existiera voluntad política de avanzar en estas cuestiones; pero, a la luz del cambio de gobierno en Andalucía a principios de 2019 y de su difícil equilibrio interno, agravado por una actitud abiertamente hostil al desarrollo de la ley entre los que sostienen dicho equilibrio, no parece que se vaya a subvertir esta situación de confusión y estancamiento.

El estudio de los Lugares de la Memoria Histórica y Democrática en Sevilla desde dos escalas analíticas ha resultado muy útil por las siguientes precisiones:

a) La escala general urbana de su memoria histórica: En esta escala es en la que se aprecian de manera más nítida las asimetrías en la identificación y asignación de valores a los lugares de la memoria histórica. El impulso que reciben desde abajo y con una visión parcial y simple del territorio (en parte ya adelantada antes), les hace perder el sentido global y unitario y esto no solo respecto a los lugares en sí (dispersos y sin conexiones), sino también con los tiempos a los que se refiere esa memoria. El golpe militar y los primeros meses de la rebelión son los que tienen más peso, pero otros períodos pierden consistencia, o ni siquiera existen (por ejemplo, el agitado período de la Sevilla republicana).

Las asimetrías y considerable confusión se corresponden en no poca medida con la responsabilidad de la propia Ley de Memoria Histórica y Democrática en materia de términos y definiciones, que acota las víctimas a aquellas personas que lucharon activamente por los derechos civiles de los andaluces. Quedan pues al margen, al menos sobre el papel, lugares en los que las víctimas no actuaron de esa forma proactiva o, sobre todo, pertenecían a sectores moderados o de derechas (que no siempre significó una actitud antirrepublicana, antidemocrática y, mucho menos, violenta). Los vencedores, que más bien se apropiaron y manipularon los hechos que acompañaron su sufrimiento, resarcieron su memoria en homenajes desde los momentos en los que ganaban los territorios, pero también debe recordarse que la grandeza de la memoria histórica es tratar por igual a quien igualmente sufrió. La injusticia es patentemente mayor en el lado de los vencidos, pero el mejor indicador de la calidad democrática de cualquier movimiento es la forma en que trata a las minorías.

Por otro lado, esta escala general ha permitido avanzar hacia el análisis reticular de estos lugares (lo que podría dar en denominarse red de Los Lugares de la Memoria Histórica y Democrática en Sevilla), a modo de subconjunto o parte integrante de la red más amplia de bienes patrimoniales de la ciudad. Al respecto, en este trabajo se han analizado conjuntamente la inserción territorial y el significado histórico de los nueve Lugares de Memoria Histórica o Democrática (declarados, incoados o en proceso) en el municipio de Sevilla. Su lectura conjunta ha sido un buen ejemplo de las aristas y asimetrías del reconocimiento de los lugares de la memoria histórica, que podría extrapolarse a toda Andalucía: no existe un programa que, ni histórica, ni espacialmente, dé claves para interpretar esta memoria $y$, menos aún, para tutelarla patrimonialmente de forma unitaria y coherente. Puede decirse de estos lugares que son todos los que están, pero que 
distan aún mucho ser estar todos los que son. El hecho de que los reconocimientos partan casi siempre de demandas sociales, a menudo de las asociaciones memorialistas, ha producido una mayor presencia ligadas a los sitios donde fueron vejadas, torturadas o asesinadas las víctimas del bando vencido (lugares de reclusión, de fusilamiento, fosas, etc.), pero no tanto donde, esas mismas víctimas, ejercieron su lucha activa para la defensa de sus derechos (ayuntamiento, gobierno civil, plaza de San Marcos, amplios sectores de los barrios de Triana y San Bernardo, etc.).

b) La escala específica de los Lugares de la Memoria Histórica y Democrática: En la segunda de las escalas se han analizado a partir de fichas la inserción, caracterización y propuestas para dos lugares de memoria en la ciudad y se han aportado algunas claves que deberían ser tenidas en cuenta en su lectura y, sobre todo, en su tutela patrimonial. Ha resultado de gran utilidad la aplicación del método a dos Lugares de Memoria Histórica y Democrática bien distintos entre sí (por tipo de declaración, por ubicación, por evolución en el tiempo y por su reconocimiento social). La determinación de sus escenarios, con sus delimitaciones concretas y sus espíritus de lugar bien diferentes, también ha permitido confirmar la versatilidad del método para adaptarse a lugares memorialistas de muy distinta consideración y significado. En esto ha jugado un papel notable la inclusión de aspectos cuantitativos fácilmente objetivables y, más aún, los cualitativos y perceptivos, más difíciles de sistematizar y valorar, pero sin duda más expresivos en la consideración final de estos lugares y su espíritu del lugar. Creemos que queda demostrada la virtualidad del método (y muy especialmente de la ficha), como estrategia para el conocimiento de los lugares memorialistas (estos u otros, españoles o pertenecientes a otros países) y para la definición de los aspectos básicos que deben ser tenidos en cuenta para su identificación, tutela y gestión.

El reconocimiento patrimonial, como valor que le asigna la sociedad a un hecho o un bien, es una tarea pendiente en Andalucía y Sevilla respecto a su memoria histórica. Se han dado pasos, pero son aún, a pesar de contar con dos leyes (una nacional y otra autonómica), balbuceantes y poco consolidados como expresión de la ausencia de un consenso social mayoritario. En esta situación se impone la necesidad perentoria de identificar los hechos y traerlos al presente sin encono y como pieza clave de la realidad identitaria de un territorio. Se avanza, pero hasta el día en el que esta memoria no sea radicalmente respetada (como por ejemplo a la hora de dar nuevos usos a la Jefatura Superior de Policía de la Gavidia) o en la conformación de espacios que honren desde la dignidad la memoria que connotan (como el lugar del fusilamiento de Blas Infante), no se podrá decir, no solo que la sociedad española, andaluza y sevillana han madurado de forma adecuada, sino que por fin se han reconciliado con esa imagen que se reflejaba en el espejo de su carácter y espíritu que no terminaba de gustar y de ser aceptada por todos. 


\section{REFERENCIAS}

Aguirre, P. (1996): Memoria y olvido de la Guerra Civil española, Alianza, Madrid. ANDRÉS SANZ, J. de (2008): «Nacionalismo español y lugares de memoria», en C. Taibo Arias (dir.), Esencias, memorias e instituciones (291-306), Los libros de La Catarata, Madrid: 291-306.

Braojos Garrido, A.; Álvarez Rey, L.; Espinosa Maestre, F. (1990): Sevilla, 1936. Sublevación y represión, Muñoz Moya y Montraveta, Sevilla.

Burgos, A. (1982). Las cabañuelas de agosto, Planeta, Barcelona.

CAHN, A.L. (2008): «El espíritu del lugar en las Cañadas Reales de la Corona de Castilla», Revista de Urbanismo, 19: 1-13.

Caro Prados, J. (2018): Lo que nos quedó por contar, Caligrama, Sevilla.

CARretero, M. (2007): La construcción de la memoria histórica en un mundo global, Paidós, Buenos Aires.

CARRIER, P. (2005): Holocaust monuments and national memory cultures in France and Germany since 1989: the origins and political function of the Vél'd'Hiv'in Paris and the Holocaust Monument in Berlin, Berghahn Books, New York / Oxford.

Colmeiro, J.F. (2005): Memoria histórica e identidad cultural: De la postguerra a la postmodernidad, Anthropos, Barcelona.

Consejería de la Presidencia, Administración Local y Memoria Democrática (2019): Informe de seguimiento de las actuaciones en materia de memoria histórica 2017-2018, Junta de Andalucía Sevilla.

DíAz Pérez, E. (2014): «La saca de la venganza. Km 4 de la carretera de Carmona», en R. LóPEZ (coord.), Lugares de la memoria. Golpe militar, represión y resistencia en Sevilla. Itinerarios, Aconcagua, Sevilla: 95-100.

EsCudero AlDAY, R. (2018): «Memoria histórica e imperio de la ley: el poder judicial ante el derecho a la reparación de las víctimas del franquismo», Derechos y Libertades: Revista de Filosofía del Derecho y Derechos Humanos, 38: 73-105. https://doi.org/10.14679/1057

Foote, K.; AZARYAHU, M. (2007): «Toward a geography of memory: Geographical dimensions of public memory and commemoration», Journal of Political and Military Sociology, 35 (1): 125-144.

García Álvarez, J. (2009): «Lugares, paisajes y políticas de memoria histórica: Una lectura geográfica», Boletín de la Asociación de Geógrafos Españoles, 51: 175-202.

García Márquez, J.M. (2019): La "Semana sangrienta" de julio de 1931 en Sevilla. Entre la historia y la manipulación, Aconcagua, Sevilla.

GiBson, I. (1986): Queipo de Llano. Sevilla. Verano de 1936, Grijalbo, Barcelona.

HaLbwachs, M. (1968): La mémoire colective, P.U.F, Paris.

Halbwachs, M.; LAsÉn, A. (1995): «Memoria colectiva y memoria histórica», Reis. Revista Española de Investigaciones Sociológicas, 69: 209-219.

Hein, L.E.; Selden, M. (2000): Censoring history: Citizenship and memory in Japan, Germany, and the United States, M. E. Sharpe, Armonk.

HeRnANDO GonZÁlez, A. (2009): «El patrimonio: Entre la memoria y la identidad de la Modernidad», Revista PH,70:88-97.https://doi.org/10.33349/2009.70.2753

Hoelscher, S.; Alderman, D. (2004): «Memory and place: Geographies of a critical relationship», Social and Cultural Geographies, 5 (83): 347-355.

Hurtado, V. (2011): La sublevación. Atlas de la Guerra Civil española, DAU, Barcelona. 
LÓPEZ FERNÁNDEZ, R., coord. (2014): Lugares de la memoria. Golpe militar, represión y resistencia en Sevilla, Aconcagua, Sevilla.

MANZINI, L. (2011): «El significado cultural del patrimonio», Estudios del patrimonio cultural, 6: 27-42.

Montestruque-Bisso, O. (2016): «Memoria y lugar. El recuerdo y olvido como forma de conservación de lo inmaterial», Limaq, 2: 143-158.

Mora Hernández, Y. (2013): «Lugares de memoria. Entre la tensión, la participación y la reflexión», Panorama, 7 (13): 97-109.

NorA, P. (1989): «Between Memory and History. Les Lieux de Mémoire». Representations, 26, 7-25.

NorA, P., dir. (1984-1992): Les lieux de mémoire, 3 vols., Gallimard, Paris.

Ortiz Villalba, J. (1998): Sevilla 1936: del golpe militar a la Guerra Civil. s.n. (impreso en Vistalegre: Córdoba): s.l.

ReY, J. (2004): El manuscrito de Ómnium Sanctórum, Algaida, Sevilla.

RIELF, D. (2017): Elogio del olvido: las paradojas de la memoria histórica, Debate, Madrid.

Riesco ChuecA, P. (2020): «De la teoría del lugar a la teoría del paisaje: no-distalidad y carácter», Boletín de la Asociación Española de Geografía, 85: 1-36. https:/ / doi. org/10.21138/bage.2858

Roigé, X. (2016): «De monumentos de piedra a patrimonio inmaterial. Estrategias políticas, museológicas y museográficas de presentación de la memoria», en I. Arrieta (ed.), Lugares de memoria traumática, Universidad del País Vasco, Bilbao: 23-47.

ROMERO GARCíA, E. (2009): Lugares de memoria e itinerarios de la Guerra Civil española, Laertes, Barcelona.

RuIz Torres, P. (2007): «Los discursos de la memoria histórica en España», Hispania Nova: Revista de Historia Contemporánea, 7: 1-30.

Salas, N. (1986): Morir en Sevilla, Almuzara, Córdoba.

Salas, N. (1992): Sevilla fue la clave. República, Alzamiento, Guerra Civil (1931-39), Castillejo, Sevilla.

Till, K. (2003): «Places of memory», en J. Agnew, K. Mitchell y G. Toal (eds.), A Companion to Political Geography (290-301), Blackwell, London: 289-301.

TsenG, Y.K.; CHEN, H.K.; Hsu, P.Y. (2013): «The use of digital images recording historical sites and «spirit of place»: A case study of Xuejia Tzu-chi Temple», International Journal of Humanities and Arts Computing, 7: 156-171. 